\title{
Assessment of tractor and all-terrain vehicle safety programs available to youth in West Virginia
}

Renee D. Chambers

West Virginia University

Follow this and additional works at: https://researchrepository.wvu.edu/etd

\section{Recommended Citation}

Chambers, Renee D., "Assessment of tractor and all-terrain vehicle safety programs available to youth in West Virginia" (2004). Graduate Theses, Dissertations, and Problem Reports. 2057.

https://researchrepository.wvu.edu/etd/2057

This Thesis is protected by copyright and/or related rights. It has been brought to you by the The Research Repository @ WVU with permission from the rights-holder(s). You are free to use this Thesis in any way that is permitted by the copyright and related rights legislation that applies to your use. For other uses you must obtain permission from the rights-holder(s) directly, unless additional rights are indicated by a Creative Commons license in the record and/ or on the work itself. This Thesis has been accepted for inclusion in WVU Graduate Theses, Dissertations, and Problem Reports collection by an authorized administrator of The Research Repository @ WVU. For more information, please contact researchrepository@mail.wvu.edu. 


\title{
Assessment of Tractor and All-Terrain Vehicle Safety
}

Programs Available to Youth in West Virginia

\author{
Renee D. Chambers
}

\author{
Thesis submitted to the \\ Davis College of Agriculture, Forestry, and Consumer Sciences \\ at West Virginia University \\ in partial fulfillment of the requirements \\ for the degree of
}

\author{
Master of Science \\ in \\ Agricultural Education
}
Harry N. Boone, Jr., Ph.D., Chair
Kerry S. Odell, Ph.D.
Patricia Miller, Ph.D.

Division of Resource Management

\author{
Morgantown, West Virginia \\ 2004
}

Keywords: Tractor Safety, All-Terrain Vehicle Safety, Youth, Extension, Agricultural Education 


\section{ABSTRACT \\ Assessment of Tractor and All-Terrain Vehicle Safety \\ Programs Available to Youth in West Virginia \\ Renee D. Chambers}

The purpose of this study was to identify the number and types of tractor and ATV safety programs available to youth in West Virginia through the Extension Service and secondary agricultural education programs. The target population of this study included county Extension agents and secondary agricultural educators in West Virginia employed during the winter of 2003-2004. A descriptive research design was utilized in this study. Thirty-five percent of Extension agents and $64.5 \%$ of agricultural educators provided tractor safety educational activities to youth. One-third of Extension agents and one-fifth of agricultural educators offered ATV safety educational activities. Age groups targeted the most by Extension agents and agricultural educators during tractor and ATV safety training were 12-14 and 15-17 year olds. The majority of Extension agents and agricultural educators felt tractor accidents were a problem in their county. A significant number of Extension agents and agricultural educators also felt ATV accidents were a problem in their county. 


\section{ACKNOWLEDGEMENTS}

Sincere appreciation is extended to the following individuals for their participation, assistance, and counsel during this study.

To the Extension agents and agricultural educators who took the time to participate in this study thanks are expressed for the valuable responses and comments.

To Dr. Harry N. Boone, thanks are expressed for serving as chairman of the thesis committee. Thank you for all your time spent answering questions, advising, and guiding me to the completion of this study. Your devotion to all students will not be forgotten.

To Dr. Kerry S. Odell, my sincere appreciation is expressed for helping me begin this study, serving on the thesis committee, and all the encouragement along the way.

To Dr. Patricia Miller, thanks are expressed for your expertise, insight, and serving on the thesis committee.

To Wayne Lundstrom, Jim Helmkamp, and the Center for Rural and Emergency Medicine, thanks are expressed for the help on developing the questionnaire and all the valuable information used in this study.

Thanks are expressed to my family for their support and understanding along the way. Sincere thanks and appreciation are extended to my husband Chris for your encouragement and patience. Thank you for helping stuff envelopes and assisting me with my schoolwork also. 


\section{TABLE OF CONTENTS}

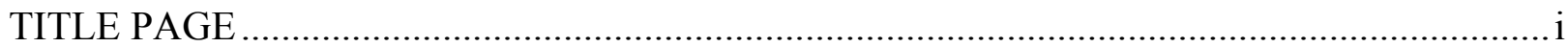

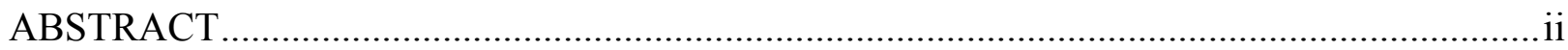

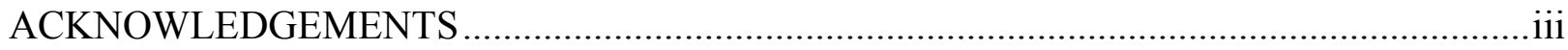

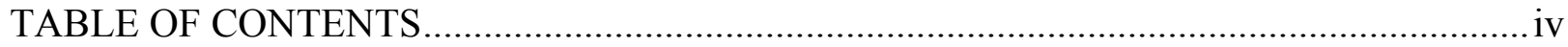

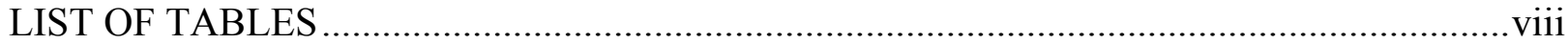

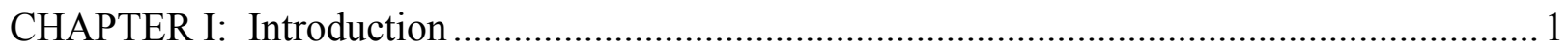

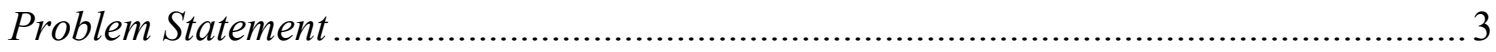

Purpose of the Study ……………………………….............................................. 3

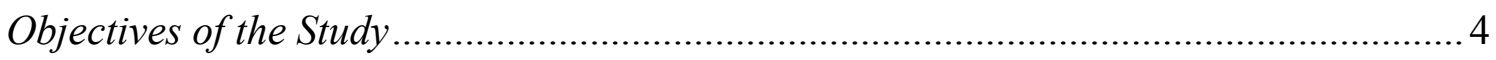

Research Questions ................................................................................................ 4

Limitations of the Study …………………………….............................................. 5

Definition of Terms ………………………………………………………………… 5

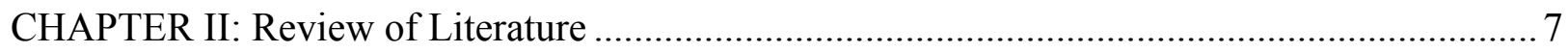

Development of Farm Safety ................................................................................ 7

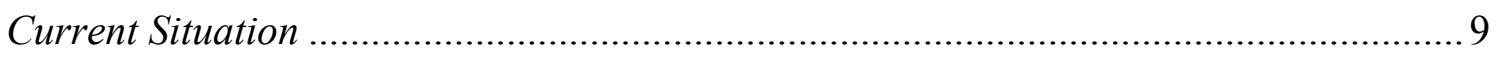

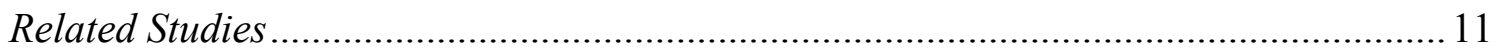

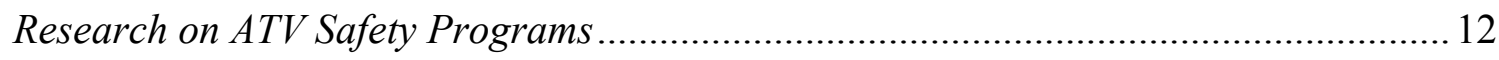

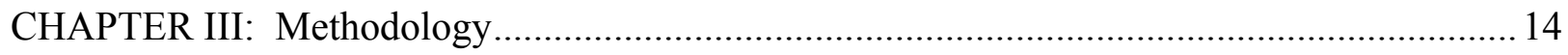

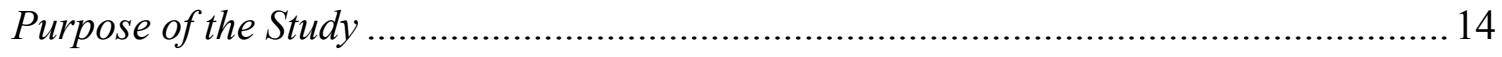

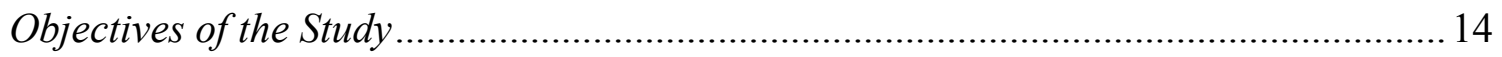

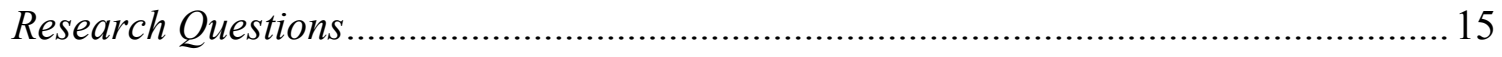

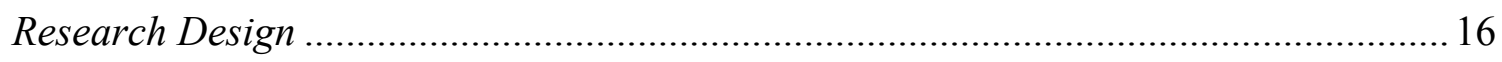

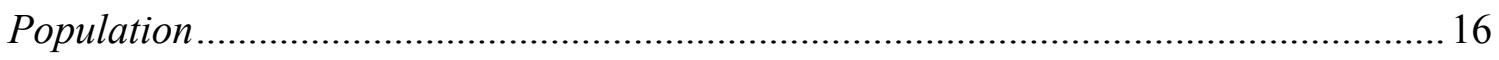




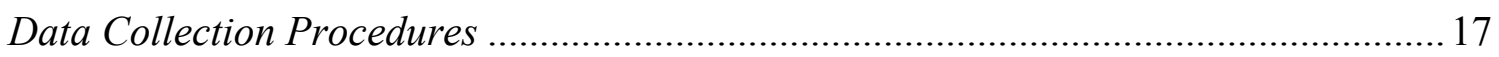

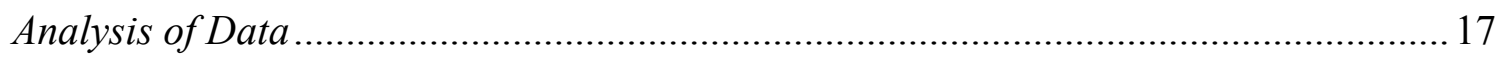

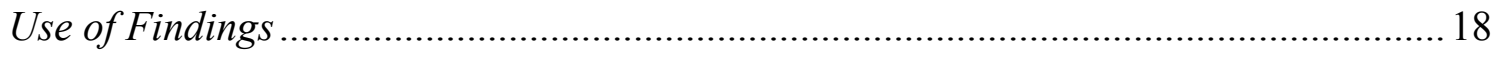

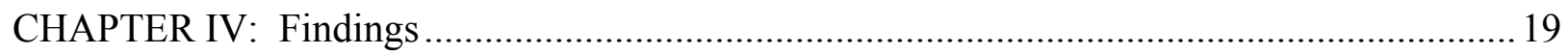

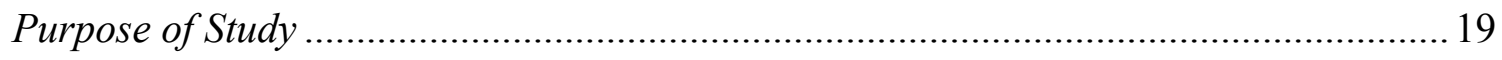

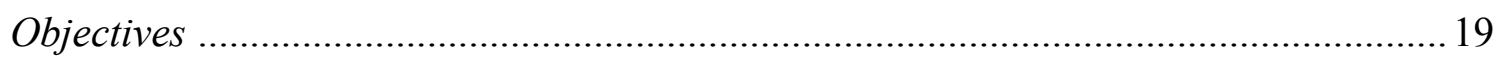

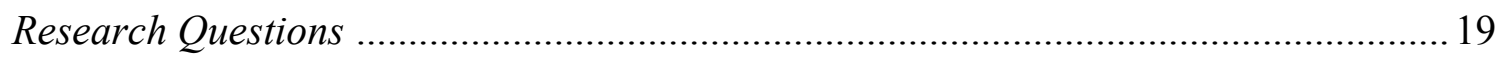

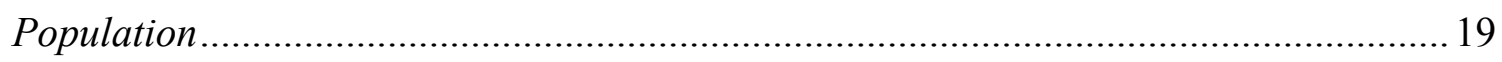

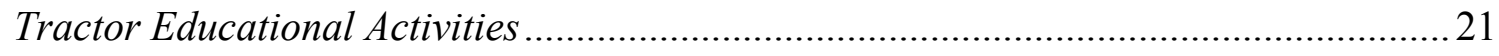

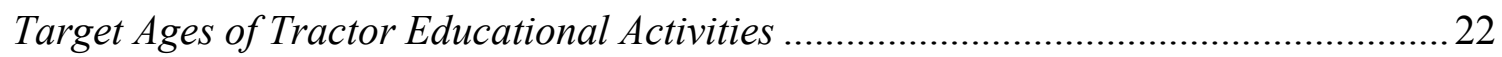

Individuals Conducting Tractor Safety Educational Activities .....................................22

Duration of Tractor Safety Educational Activities ...........................................................24

Individuals Who Developed the Tractor Safety Educational Activities...........................25

Methods of Instructions for Tractor Safety Educational Activities ................................2

How Often Were Tractor Safety Activities Presented ..................................................26

Number of Youth Participants in the Tractor Safety Educational Activities ....................27

Youth to Whom Tractor Educational Activities were Available ......................................28

Topics Covered in Tractor Educational Activities.........................................................2 29

Effectiveness of Tractor Safety Educational Activities as Perceived by

Extension Agents and Agricultural Educators............................................................ 30

Opportunities for Youth Certification on Tractor Safety ................................................... 31

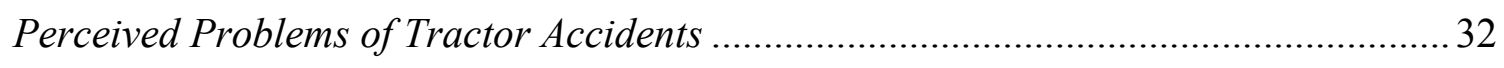


Additional Tractor Safety Programs........................................................................... 32

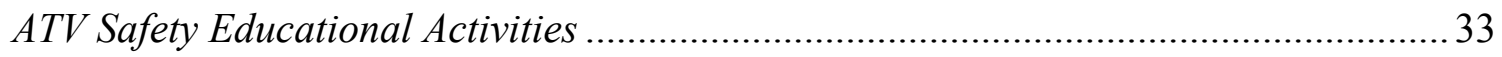

Target Ages of ATV Educational Activities …………………………………………..... 34

Individuals Who Conducted the ATV Safety Activities ..................................................... 35

Duration of ATV Safety Educational Activities ............................................................... 36

Individuals Who Developed the ATV Safety Educational Activities ................................37

Methods of Instruction for ATV Safety Educational Activities ........................................38

How Often Were the ATV Safety Educational Activities Presented... .............................39

Number of Youth Participants in the ATV Safety Educational Activities .......................40

Youth To Whom ATV Safety Educational Activities Were Available ................................ 41

Topics Covered in ATV Educational Activities..........................................................42

Effectiveness of ATV Safety Educational Activities as Perceived by

Extension Agents and Agricultural Educators ............................................................... 43

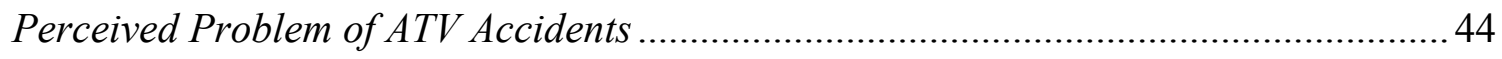

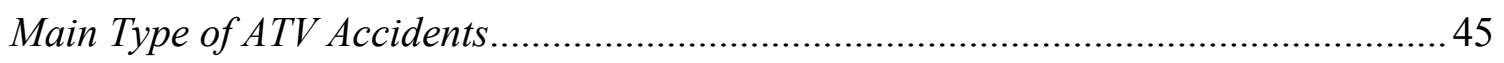

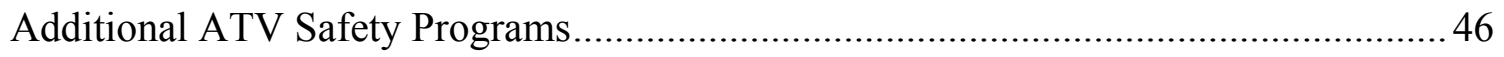

CHAPTER V: Summary, Conclusions, and Recommendations .................................................. 48

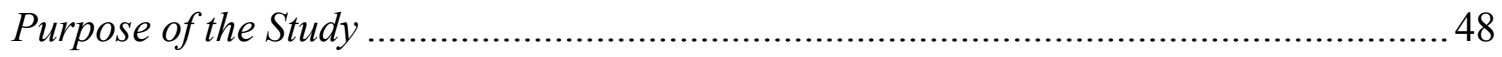

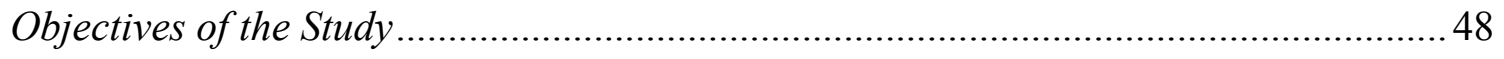

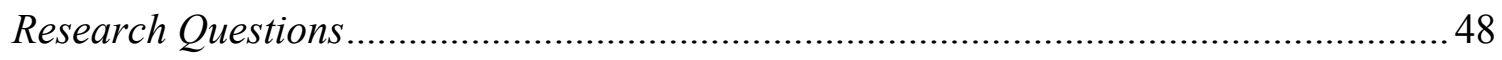

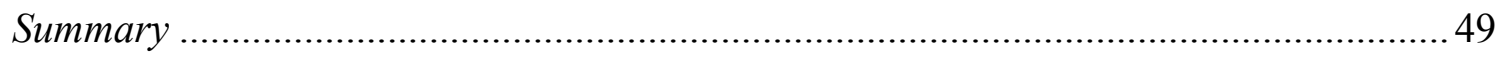

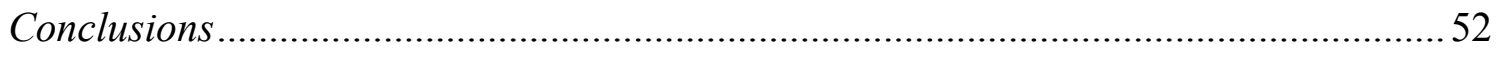

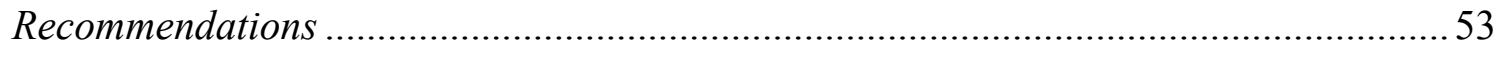

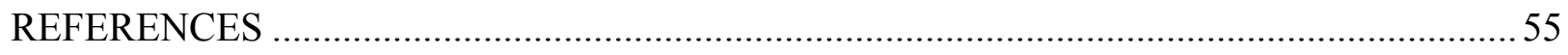

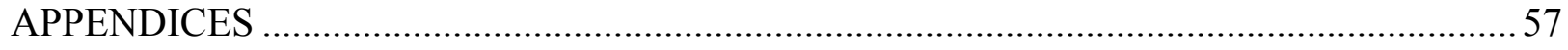


APPENDIX A: Cover Letter

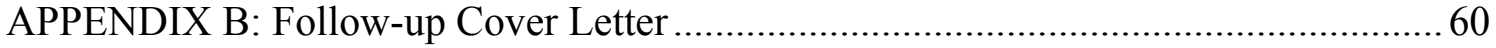

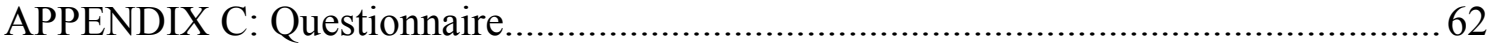

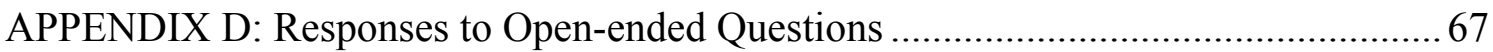

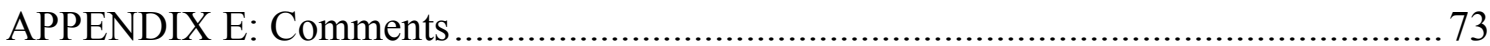

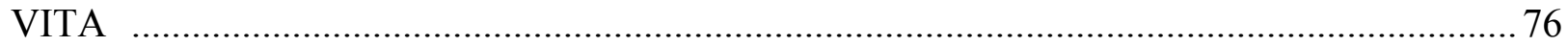




\section{LIST OF TABLES}

Table

Page

1. Tractor Safety Educational Activities Provided by Extension Agents and

Agricultural Education Teachers

2. Target Ages for Tractor Educational Activities Provided by Extension

Agents and Agriculture Education Teachers....

3. Who Conducted Tractor Educational Activities?

4. Duration of Tractor Educational Activities

5. Individuals/Groups who Developed the Tractor Safety Educational

Activities

6. Methods of Instruction for Tractor Safety Educational Activities.

7. How Often Were Tractor Safety Activities Presented?

8. Number of Youth Participants in Tractor Safety Educational Activities

9. Youth to Whom Tractor Educational Activities Were Available

10. Topics Covered in Tractor Educational Activities

11. Effectiveness of Tractor Safety Educational Activities as Perceived by

Extension Agents and Agricultural Educators....

12. Certification Offered for Tractor Educational Activities..............................................31

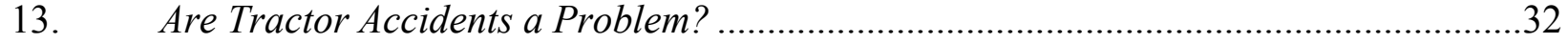

14. Are Additional Tractor Safety Programs Needed? ....................................................33

15. ATV Educational Activities Provided by Extension Agents and Agricultural Education Teachers

16. Target Ages of ATV Educational Activities Provided by Extension Agents and Agricultural educators.

17. Individuals who Conducted ATV Educational Activities .36 
18. Duration of ATV Educational Activities

19. Individuals who Developed the ATV Safety Educational Activities...............................38

20. Methods of Instruction for ATV Safety Educational Activities .....................................39

21. How Often Were ATV Safety Activities Presented? .................................................40

22. Number of Youth Participants in Tractor Safety Educational Activities ......................41

23. Youth to Whom ATV Educational Activities were Available .......................................42

24. Topics Covered in ATV Educational Activities .........................................................43

25. Effectiveness of ATV Safety Educational Activities as Perceived by Extension Agents and Agricultural Educators..........................................................44

26. Are ATV Accidents Perceived as a Problem?...............................................................45

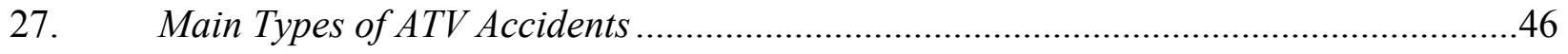

28. $\quad$ Are Additional ATV Safety Programs Needed? .......................................................47 


\section{CHAPTER I}

Introduction

America's 2.1 million farms and ranches are home and workplace to approximately 3.2 million men and women (U.S. Department of Labor, 1995). According to statistics reported by the National Safety Council, when compared to all other industries, the agricultural industry has the highest incidence of occupational illness and injury (U.S. Department of Labor, 1995). The New York Center for Agricultural Medicine and Health (2002) considers farming to be the most dangerous industry in the United States. In most industrial situations, great strides have been made in eliminating or reducing occupational hazards, largely through regulations that are enforced by employers, unions and government agencies. Such regulatory mechanisms do not affect the farmer, whose safety precautions are self-imposed and who is free to operate with or without suggested safety standards in place. Farm accidents and other agricultural-related health problems claim as many as 1400 lives and contribute to 140,000 injuries per year as indicated in Accident Facts published by the National Safety Council (1992). The injury rate is highest among children age 15 and under and adults over 65. The majority of farming accidents involve machinery (U.S. Department of Labor, 1995). Studies show that the farm machinery death rate increased by 44\% between the years 1930 and 1980 (Stoskopf \& Venn, 1985). The tractor is directly related to over half of reported farm fatalities (New York Center for Agricultural Medicine \& Health, 2002).

Economic costs are also associated with agriculture-related injuries, illnesses, and deaths. According to a New York study of people killed in farm accidents it was estimated that between $\$ 218,001.00$ and $\$ 362,047.00$ of lifetime expected income and opportunity costs (per person) were incurred as a result of farm accidents (Kelsey, 1991). Included in these costs were health 
care, discounted future earnings, and special devices such as wheel chairs and lifts. As a result of some farm-related accidents, the farm has to be sold to pay for medical expenses. When the family is unable to pay the medical expenses, society assumes much of the costs (Anderson \& Magleby, 1997).

The agricultural industry is unique in that the farm is not only workplace, but also home to many families. Children are at special risk of farm-related accidents because they live, work, and play in dangerous areas. Farm accidents claim the lives of as many as 300 children per year (U.S. Department of Labor, 1995). Equipment, animals, chemicals, pesticides, and feed storage tanks have the potential to harm children if they are not stored or handled properly. Many accidents involve children as bystanders or passengers on equipment. On many farms it is a common practice for children to operate farm machinery. A survey conducted in Indiana reported that the age when tractor operation was first allowed ranged from 4 to 16 years of age, with the average being 11 years of age (Carrabba, Talbert, Field, \& Tormoehlen, 2001). According to farm facts, published by the United States Department of Labor (1995), farm machinery, including tractors accounts for $36 \%$ of all fatalities and is the leading cause of death to youth less than 20 years of age.

Another agent of serious accidents to youth is All-terrain vehicles (ATVs). ATVs are popular for use as recreation and for work on the farm. In a 1997 survey conducted by the National Children's Center for Rural and Agricultural Health and Safety it was estimated that 826,000 U.S. children under the age of 16 operate ATV's (2000). As the popularity of ATV's has increased, so has the number of ATV-related injuries and. According to the National Children's Center for Rural and Agricultural Health and Safety (2000), the estimated number of ATV-related injuries requiring emergency medical attention for children under 16 years of age in 
the U.S. grew from 19,300 to 28,700 annually from the years 1995 to 1999 . Factors associated with the increased risk of operating ATVs for youth included: not wearing a helmet, immature judgement/risk taking behavior, and riding with a passenger (National Children's Center for Rural and Agricultural Health and Safety, 2000).

\section{Problem Statement}

It is important to understand and acknowledge the unique health and safety issues of youth in agriculture. There are 20,000 farms in West Virginia and nearly four million acres of farmland (U.S. Census Bureau, 2003). Many children live and work on farms in West Virginia and are exposed to agricultural hazards daily. In many situations children are not adequately supervised, have not received proper training and/or are attempting to do something beyond their physical and judgmental capabilities (National Safety Council, 2001). In order to reduce the number of tractor and ATV-related injuries among youth in West Virginia, appropriate information on safety programs is needed. A review of literature failed to reveal information on the number and types of educational safety programs available for youth in West Virginia. This information needs to be collected, assessed, and made available to individuals involved in safety and education.

Purpose of the Study

The purpose of this research was to identify the number and types of tractor and ATV safety programs available to youth in West Virginia through the Extension Service and secondary agricultural education programs. This information will be useful to safety professionals and educators in planning additional safety programs for youth in West Virginia. 


\section{Objectives of the Study}

The primary objective of the research was to identify tractor and ATV safety programs available to youth in West Virginia through the Extension service and secondary agricultural education programs.

Secondary objectives included:

1. Identify the number of tractor and ATV safety programs available to youth in West Virginia through the Extension Service and secondary agricultural education programs.

2. Determine the types of safety programs available to youth in West Virginia through the Extension Service and secondary agricultural education programs.

3. Determine how often these programs were offered.

4. Determine the perceptions of Extension Agents and secondary agricultural teachers toward these programs.

\section{Research Questions}

1. How many secondary agricultural educators and Extension agents offer tractor safety educational activities to youth in West Virginia?

2. What age groups were targeted by the tractor safety educational activities offered by the agricultural educators and Extension agents?

3. What topics were covered in the tractor safety educational activities?

4. What methods of instruction were utilized during the tractor safety educational activities?

5. Did agricultural educators and Extension agents feel that tractor accidents are a problem in their county? 
6. Did agricultural educators and Extension agents feel that more tractor safety programs are needed in their county?

7. How many secondary agricultural educators and Extension agents offer ATV safety educational activities to youth in West Virginia?

8. What age groups were targeted by the ATV safety educational activities offered by the agricultural educators and Extension agents?

9. What topics were covered in the ATV safety educational activities?

10. What methods of instruction were utilized during the ATV safety educational activities?

11. Did agricultural educators and Extension agents feel that ATV accidents are a problem in their county?

12. Did agricultural educators and Extension agents feel the main cause of ATV accidents is agricultural or recreational use?

13. Did agricultural educators and Extension agents feel that more ATV safety programs are needed in their county?

\section{Limitations of the Study}

This study was limited to West Virginia Extension agents and secondary agricultural education teachers who held positions during the winter of 2003-2004.

Definition of Terms

Agricultural Industry - encompasses the production of commodities including food, fiber, wood products, horticultural crops, and other plant and animal products. 
All-Terrain Vehicle (ATV) - three- or four-wheeled vehicle with low-pressure tires, powered by a gasoline engine.

Extension Service - those personnel involved in research and disseminating new information from universities to the community.

Power Take-Off (PTO) Shaft - a shaft that spins to transfer power from the tractor to the implement behind it, rotations occur at a very high rate of 540 or 1,000 rotations per minute.

Safety Programs - educational classes designed to prevent or protect against accident or injury.

Tractor - two or four wheel drive vehicle or more than 20 engine horsepower, designed to furnish the power to pull, carry, propel, or drive implements that are designed for agriculture.

Youth - refers to persons 18 years of age or younger. 


\section{CHAPTER II}

\section{Review of Literature}

\section{Development of Farm Safety}

Industrial safety efforts began in the late 1800's because of demands from laborers for safer working environments. These demands were the consequence of high accidents rates. This early legislation focused mainly on the mining and railroad industries, and few efforts were made toward farm safety during this time. The American Industrial Safety and Health movement began in the years 1906-1912. The first Cooperative Safety Congress, which marked the beginning of organized safety on a national scale, met in 1912 in Milwaukee, Wisconsin. The First Cooperative Safety Congress was primarily concerned with safety among the nations industries. In the following year, 1913, the National Safety Council (NSC) was established. Safety organizations continued to be established, and as a result safety publications, pamphlets, and films were created (Zink, 1999).

It wasn't until 1936 that the NSC requested to have a farm safety program. This request was fulfilled at the 1937 National Safety Congress, when it was made known that agriculture, the nation's largest and oldest industry, still did not have a safety program of its own. At the meeting, the NSC organized a separate program for farm safety. The participants at the first farm safety conference were concerned with developing a program to prevent agricultural accidents. Accident statistics at that time showed that injuries and fatalities in agriculture occurred at a much higher rate than in other industries (Zink, 1999).

It was also in the year 1937 that the uniform power take-off (PTO) shield was proposed. The PTO shaft is a shaft that spins to transfer power from the tractor to the implement behind it. It rotates at a very high rate of 540 or 1,000 rotations per minute (New York Center for 
Agricultural Medicine and Health, 2002). Loose clothing or long hair may become entangled in the PTO shaft resulting in disabling injury or death. The proposed shield would guard the PTO shaft and protect objects from becoming entangled in the shaft. In 1944 the PTO standard was adopted. In 1943, Wisconsin became the first state to appoint a farm safety specialist in the agricultural extension service. Twelve more farm safety specialists were appointed in the next ten years. In 1943 the NSC created a separate Farm Division (Zink, 1999).

In 1970 the Occupational Safety and Health Act established the Occupational Safety and Health Administration (OSHA). OSHA is responsible for overseeing health and safety in the workplace. According to the national Children's Center for Rural and Agricultural Health and Safety:

All agricultural operations of one or more workers engaged in a business that affects interstate commerce must comply with OSHA regulations except:

1) farm operations employing only their own family members, and

2) farm operations which have 10 or fewer employees during the previous 12 months and do not maintain a migrant labor camp.

OSHA has the authority to:

- Set standards

- Inspect workplaces

- Cite violations

- Impose penalties and asses fines up to $\$ 10,000$ for child labor violations

- Shut down operations

- Allow employees participation (National Children's Center for Rural \& Agricultural Health \& Safety, 2002a). 
These standards affect less than five percent of the farms in the United States according to the 1992 U.S. Census of Agriculture. Many farms are family owned and operated or they have fewer than ten workers, which excludes them from these regulations. Farmers are essentially self-regulated and may or may not choose to follow safety guidelines. Also farm equipment such as the tractor, unlike highway vehicles or consumer products, does not have to meet federal government standards for safety. In 1976 OSHA did impose standards requiring rollover protective structures (ROPS) on all tractors used by employees, however this standard does not apply to tractor operators who are self-employed or farm family members (Karlson \& Noren, 1979). The Hazardous Occupation Orders for Agriculture (HOOA) sets regulations for children under the age of sixteen, however these do not apply to children that are employed by their parents or persons acting as their parents (National Children's Center for Rural \& Agricultural Health \& Safety, 2002b). These regulations also affect only a very small portion of the farms in the United States.

\section{Current Situation}

Agriculture continues to be the most dangerous industry in the United States (New York Center for Agricultural Medicine and Health, 2002). According to Stoskopf and Venn (1985), the farm machinery death rate has increased by $44 \%$ between the years of 1930 and 1980 ; however, the death rate for injuries resulting from all other machinery has dropped by nearly $80 \%$. Through the years, mechanization and technological advancements have brought increased productivity and efficiency to the farming industry. These advancements have also increased the risk of accidents because equipment is more powerful and complex, requiring the full attention of the operator. Tractors are indispensable pieces of machinery in the farming industry. They allow farmers to work more efficiently, but are the deadliest machine on the farm. As reported 
in Trac-Safe: A Community-Based Program for Reducing Injuries and Deaths from Tractor

Overturns (U.S. Department of Health and Human Service, 1996), the tractor is the machine most often involved in farm fatalities, with the tractor overturn being the most common cause of death from tractors.

The agricultural industry is unique in that the farm is not only the workplace, but also home and recreational area for many families. Other high-risk industries such as mining, construction, and transportation rarely have children at the worksite, in contrast to the agricultural industry (Lee, Gallagher, Marlenga, \& Hard, 2002). According to a fact sheet on agricultural safety and children published by the National Children's Center for Rural and Agricultural Health and Safety (2002a), fatality rates among young workers in agriculture are three times greater than fatality rates of young workers in the private sector. The estimated number of farms in the United States in 1999 was over 2.19 million. The estimated number of youth that lived on farms in 1998 was 1.26 million (National Children's Center for Rural and Agricultural Health and Safety, 2002a).

Children may also operate machinery before they have the physical, mental, and emotional abilities to do so. An Indiana farm safety survey reported that children were first allowed to operate a tractor between the ages of 4 and 16 with the average age being 11 (Carrabba, Talbert, Field, \& Tormoehlen, 2001). Children are also often involved in accidents as bystanders.

Another cause of child fatalities involving tractors is allowing children to ride as passengers. Tractors are designed for only one person, the operator and no passengers. Passengers, especially children because of their lighter body weight, are the first to be bumped off a tractor during a rough ride. Passengers can also distract operators or limit the operator's 
field of vision. A study of Pennsylvania tractor operators indicated that parents have an increased tendency to allow children on tractors as passengers (Ambe, Bruening, \& Murphy 1994).

\section{Related Studies}

Farmers in the state of West Virginia are actively involved in numerous types of agricultural production. A five-year study, conducted by the Center for Rural and Emergency Medicine (CREM) (2002), analyzed the number and type of tractor-related fatalities among West Virginia farmers. According to this study, 37 people were killed between January 1997 and July 2002. Of the 37 deaths, 29 (79\%) were the result of tractor overturn or runovers. Two deaths (5\%) were directly related to the PTO shaft. The remaining six deaths (16\%) were categorized as other. These deaths occurred in 26 of the 55 counties in West Virginia (CREM, 2002).

Another safety concern for farmers as well as the general population is ATV-related injuries. The growing popularity of ATVs has also increased the number and severity of ATVrelated accidents. From 1995 to 1999, the estimated number of U.S. children under the age of 16 having ATV-related injuries requiring emergency medical care grew annually from 19,300 to 28,700, which represents a 33\% increase. From 1982 to 1999 1,310 children under the age of 16 died as a result of an ATV accident (National Children's Center for Rural and Agricultural Health and Safety, 2000a). A survey conducted in 1997 by the National Children's Center for Rural and Agricultural Health and Safety (2000) estimated that 826,000 children less than 16 years of age operate ATVs. Factors associated with the high number of ATV accidents for youth are: a) not using a helmet, b) immature judgment / risk taking behavior, and c) riding with a passenger (National Children's Center for Rural and Agricultural Health and Safety, 2000a). An ongoing study conducted by CREM (2002b) revealed that since the year 2000 there has been 63 
ATV-related deaths in 33 of the 55 counties in West Virginia. Until recently, West Virginia was one of the seven states that did not have some level of ATV safety legislation. West Virginia averaged about 13 ATV-related deaths per year from 1990 until 1999. The average annual ATVrelated death rate has risen to 21 deaths per year since January 2000 (CREM, 2002b). Research on ATV Safety Programs

A review of literature did not reveal any specific information on tractor/ATV safety programs for youth in West Virginia. Although unsubstantiated information was found, there was no hard evidence to support this material. Other states are actively involved in educating youth on tractor safety. Indiana has been involved in a 4-H tractor program to educate children on tractor safety. A survey conducted on the effectiveness of the program showed that the majority $(97.1 \%)$ agreed or strongly agreed that the 4-H Tractor Program was effective at educating youth to be safe tractor and machinery operators (Carrabba et al., 2001). A majority (89.9\%) also agreed or strongly agreed that the program also benefited them in other areas of their life. These benefits included mechanical knowledge, operation of other machines, communication skills, self-confidence, career exploration, leadership skills, general safety awareness, and responsibility (Carrabba et al., 2001).

At Iowa Sate University, the Extension Service developed Trac-Safe, which is a community-based program for reducing tractor-related injuries and deaths (U. S. Department of Health \& Human Service, 1996). Trac-Safe included a manual, which is used as a facilitator's guide and can be used in any type of community education program. The manual provided suggestions for a planning committee to organized, develop, implement, and evaluate the program (U. S. Department of Health \& Human Service, 1996). There is a definite need to determine the number and type of programs available to youth in West Virginia. Data will be 
useful to professionals involved in farm safety, such as the Extension Service and the Center for Rural and Emergency Medicine (CREM), to develop new and more effective programs to prevent farm and ATV accidents. 


\section{CHAPTER III}

\section{Methodolgy}

\section{Purpose of the Study}

The purpose of this study was to determine the number and types of tractor and ATV safety programs available for youth in West Virginia through the county Extension Service and secondary agriculture education programs. Another purpose was to determine the perceptions of Extension agents and secondary agricultural educators of the effectiveness of these programs. Safety professionals, teachers and Extension agents may use the findings of this research to develop more effective safety programs. Other researchers who have an interest in tractor safety may also use the finding of this research.

\section{Objectives of the Study}

The primary objective of the research was to identify tractor and ATV safety programs available to youth in West Virginia through the Extension service and secondary agricultural education programs.

Secondary objectives included:

1. Identify the number of tractor and ATV safety programs available to youth in West Virginia through the Extension Service and secondary agricultural education programs.

2. Determine the types of safety programs available to youth in West Virginia through the Extension Service and secondary agricultural education programs.

3. Determine how often these programs were offered.

4. Determine the perceptions of Extension Agents and secondary agricultural teachers toward these programs. 


\section{Research Questions}

1. How many secondary agricultural educators and Extension agents offer tractor safety educational activities to youth in West Virginia?

2. What age groups were targeted by the tractor safety educational activities offered by the agricultural educators and Extension agents?

3. What topics were covered in the tractor safety educational activities?

4. What methods of instruction were utilized during the tractor safety educational activities?

5. Did agricultural educators and Extension agents feel that tractor accidents are a problem in their county?

6. Did agricultural educators and Extension agents feel that more tractor safety programs are needed in their county?

7. How many secondary agricultural educators and Extension agents offer ATV safety educational activities to youth in West Virginia?

8. What age groups were targeted by the ATV safety educational activities offered by the agricultural educators and Extension agents?

9. What topics were covered in the ATV safety educational activities?

10. What methods of instruction were utilized during the ATV safety educational activities?

11. Did agricultural educators and Extension agents feel that ATV accidents are a problem in their county?

12. Did agricultural educators and Extension agents feel the main cause of ATV accidents is agricultural or recreational use? 
13. Did agricultural educators and Extension agents feel that more ATV safety programs are needed in their county?

\section{Research Design}

This study utilized descriptive survey research to obtain data on tractor and ATV safety programs available to youth in West Virginia. A survey was designed by the researcher along with the help of the research committee and survey specialists at the Center for Rural and Emergency Medicine (CREM). Descriptive survey design was utilized in order to gain new insights or describe characteristics of a situation. Descriptive research also allows the researcher to gather data from a fairly large group of persons at one point in time (Kaplin, 1991).

\section{Population}

The target population of this study included county Extension agents and secondary agricultural educators in West Virginia employed during the winter of 2003-2004. The names of the individual secondary agricultural teachers were obtained from the West Virginia Secondary Agriculture Teachers and Schools Directory. The names of individual extension agents were obtained from a directory of all extension agents in West Virginia. These two groups were chosen as the target population for this study due to their close contact with youth in a setting in which agricultural safety training may occur. Sampling errors were avoided by including the entire population in this study. Frame error was avoided by using official address list from the West Virginia Secondary Agriculture Teachers and Schools Directory. An official list of all Extension agents was obtained from West Virginia University Extension Service. The surveys were mailed to the home addresses of the agricultural educators and the extension offices of the extension agents. To reduce/eliminate non-response error, procedures for administering mail questionnaires and follow-up procedures recommended by Dillman (1978) were followed with 
slight modifications. The modification was no reminder postcard was sent. A panel of experts at West Virginia University established face and content validity of the instrument and reliability was determined using Spearman-Brown split half statistic. Reliability was found to be exemplary with a coefficient of 0.87 (Robinson, Shaver, \& Wrightsman, 1991).

\section{Data Collection Procedures}

The data collection procedures used in this study included a cover letter (see Appendix A), questionnaire (see Appendix C), and postage paid self-addressed return envelope. The cover letter explained the purpose of the study, importance of the participants' cooperation in the study, assurance of confidentiality, a statement of non-obligation, and instructions for completing and returning the survey. It also included a statement of thanks for those participants responding to the survey. The surveys were color coded to identify between the groups of agricultural educators and Extension agents. The surveys were also coded for the purpose of sending a second questionnaire to non-respondents. The initial surveys were mailed on September 8, 2003. Participants were asked to complete and return the survey by September 26. A follow up letter (see Appendix B) and a second questionnaire were sent to each non-respondent on October 8, 2003, thirty days after the initial survey was mailed. A second deadline for response was set for October 15. Surveys were again coded using a separate color for extension agent, and agricultural educators. Early and late respondents were tracked. Analysis of Data

Returned questionnaires were examined visually and entered into a Microsoft Excel spreadsheet. The data were transferred to the Statistical Package for the Social Sciences (SPSS). Descriptive comparative data were derived through frequencies. Differences were found 
between responses of early and late respondents at $($ alpha $<=0.05)$ therefore generalizations were limited to the respondents.

Use of Findings

Findings of this research may be used by safety professionals and others involved in youth tractor and ATV safety. Findings will be provided to the Center for Rural and Emergency Medicine (CREM) and the West Virginia Council for ATV Safety. Based upon the results of this study, interested individuals will be able to ascertain the extent to which agricultural educators and extension agents are involved in tractor and ATV safety programs. 


\section{CHAPTER IV}

\section{Findings}

\section{Purpose of the Study}

The purpose of the study was to identify the number and types of tractor and ATV safety programs available to youth in West Virginia through the Extension Service and secondary agricultural education programs. This information will be useful to safety professionals and educators in planning additional safety programs for youth in West Virginia.

\section{Objectives of the Study}

The primary objective of the research was to identify tractor and ATV safety programs available to youth in West Virginia through the Extension service and secondary agricultural education programs.

Secondary objectives included:

1. Identify the number of tractor and ATV safety programs available to youth in West Virginia through the Extension Service and secondary agriculture education teachers.

2. Determine the types of safety programs available to youth in West Virginia through the Extension Service and secondary agriculture education programs.

3. Determine how often these programs are offered.

4. Determine the perceptions of Extension Agents and secondary agricultural educators toward these programs.

\section{Research Questions}

1. How many secondary agricultural educators and Extension agents offer tractor safety educational activities to youth in West Virginia? 
2. What age groups were targeted by the tractor safety educational activities offered by the agricultural educators and Extension agents?

3. What topics were covered in the tractor safety educational activities?

4. What methods of instruction were utilized during the tractor safety educational activities?

5. Did agricultural educators and Extension agents feel that tractor accidents are a problem in their county?

6. Did agricultural educators and Extension agents feel that more tractor safety programs are needed in their county?

7. How many secondary agricultural educators and Extension agents offer ATV safety educational activities to youth in West Virginia?

8. What age groups were targeted by the ATV safety educational activities offered by the agricultural educators and Extension agents?

9. What topics were covered in the ATV safety educational activities?

10. What methods of instruction were utilized during the ATV safety educational activities?

11. Did agricultural educators and Extension agents feel that ATV accidents are a problem in their county?

12. Did agricultural educators and Extension agents feel the main cause of ATV accidents is agricultural or recreational use?

13. Did agricultural educators and Extension agents feel that more ATV safety programs are needed in their county? 


\section{Population}

The target population for this study consisted of 98 secondary agricultural educators and 89 Extension agents employed in West Virginia during the winter of 2003-2004. Of the 187 mailed surveys, two were returned due to invalid addresses, making the accessible population 185 agricultural educators and Extension agents. One hundred and twenty-three of the 185 surveys were returned with usable data resulting in a $66 \%$ response rate. Nine of the surveys were not used because respondents returned surveys in response to both the first and second mailings. Of the total 123 respondents, 62 (50.4\%) were secondary agricultural educators and 61 (49.6\%) were Extension agents. Ninety-five (77.2\%) participants responded to the first mailing and were classified as early respondents. Twenty-eight (22.8\%) participants responded to the second mailing and were classified as late respondents.

\section{Tractor Educational Activities}

Twenty-one (35\%) Extension agents and 40 (64.5\%) agricultural educators offered educational activities to youth that included tractor safety. Overall 61 of the respondents $(50.0 \%)$ offered tractor safety educational activities to youth in their jurisdiction (see Table 1$)$.

Table 1

Tractor Safety Educational Activities Provided by Extension Agents and Agricultural Education Teachers

\begin{tabular}{lcccccc}
\hline & \multicolumn{2}{c}{ Extension } & \multicolumn{2}{c}{ Ag Teacher } & \multicolumn{2}{c}{ Total } \\
\cline { 2 - 6 } & $N$ & $\%$ & $N$ & $\%$ & $N$ & $\%$ \\
\hline Yes & 21 & 35.0 & 40 & 64.5 & 61 & 50.0 \\
No & 39 & 65.0 & 22 & 35.5 & 61 & 50.0 \\
Total & 60 & 100.0 & 62 & 100.0 & 122 & 100.0 \\
\hline
\end{tabular}




\section{Target Ages of Tractor Educational Activities}

Individuals who offered tractor safety activities were asked to identify all age group(s) that were targeted. Two Extension agents (9.5\%) targeted youth less than eight years of age, 15 (71.4\%) targeted youth eight -11 years of age, 14 (66.7\%) targeted youth 12-14 years of age, 12 (57.1\%) targeted youth $15-17$ years of age, and eight (38.1\%) targeted persons 18 years of age and older. Four agricultural educators (10.0\%) targeted youth eight -11 years of age, $17(42.5 \%)$ targeted youth 12-14 years of age, 37 (92.5) targeted youth 15-17 years of age, and $11(27.5 \%)$ targeted persons 18 years of age and older (see Table 2).

Table 2

Target Ages for Tractor Educational Activities Provided by Extension Agents and Agriculture Education Teachers

\begin{tabular}{lcccc}
\hline & \multicolumn{2}{c}{ No } & \multicolumn{2}{c}{ Yes } \\
\cline { 2 - 5 } & $N$ & $\%$ & & \\
\hline Extension & 19 & 90.5 & 2 & 9.5 \\
$<8$ year olds & 6 & 28.6 & 15 & 71.4 \\
$8-11$ & 7 & 33.3 & 14 & 66.7 \\
$12-14$ & 9 & 42.9 & 12 & 57.1 \\
$15-17$ & 13 & 61.9 & 8 & 38.1 \\
18 or older & & & & \\
Ag Teachers & 40 & 100.0 & 0 & 0.0 \\
$<8$ year olds & 36 & 90.0 & 4 & 10.0 \\
$8-11$ & 23 & 57.5 & 17 & 42.5 \\
$12-14$ & 3 & 7.5 & 37 & 92.5 \\
$15-17$ & 29 & 72.5 & 11 & 27.5 \\
18 or older & & & & \\
\hline
\end{tabular}




\section{Individuals Who Conducted Tractor Safety Educational Activities}

Participants were asked to identify the individuals/groups who conducted the tractor safety educational activities. Fifteen Extension agents (83.3\%) responded that tractor safety educational activities were conducted by Extension agents, and two agents $(11.1 \%)$ responded that an Extension agent and agricultural education teacher conducted the activities. The agriculture education teachers responded that $35(87.5 \%)$ tractor safety educational activities were conducted by a secondary agricultural education teacher and five (12.5\%) responded that both an agricultural education teacher and an Extension agent conducted the activities (see Table 3). In an open-ended other category, 14 respondents (11.4\%) indicated others conducted the activities. Some respondents wrote in more than one response for the others category for a total of nine different responses. These include Farm Bureau, Progressive Farmer, FFA students, FFA Alumni, 4-H leaders, teen leaders, the fire department, and volunteers (see Appendix D).

Table 3

Individuals Who Conducted Tractor Safety Educational Activities?

\begin{tabular}{lcccccc}
\hline & \multicolumn{2}{c}{ Extension } & \multicolumn{2}{c}{ Ag Teacher } & \multicolumn{2}{c}{ Total } \\
\cline { 2 - 7 } & $N$ & $\%$ & $N$ & $\%$ & $N$ & $\%$ \\
\hline No Answer & 1 & 5.6 & 0 & 0 & 1 & 1.7 \\
County Extension Agent & 15 & 83.3 & 0 & 0 & 15 & 25.9 \\
Agriculture Teacher & 0 & 0 & 35 & 87.5 & 35 & 60.3 \\
Both Extension and Ag Teacher & 2 & 11.1 & 5 & 12.5 & 7 & 12.1 \\
Total & 18 & 100.0 & 40.0 & 100.0 & 58 & 100.0 \\
\hline
\end{tabular}




\section{Duration of Tractor Safety Education Activities}

Fifteen (75.0\%) Extension agents reported tractor safety educational activities were conducted for half a day or less. Four (20.0\%) Extension agents reported that the activities were conducted for one to two days. One Extension agent (5.0\%) reported other as the duration for the tractor safety activities. Seven (17.5\%) agricultural educators reported tractor safety activities were conducted for half a day or less. Seventeen (42.5\%) reported the activities were conducted for one to two days. Thirteen (32.5\%) reported the activities were conducted for three to four days. Three agricultural educators (7.5\%) reported other as the duration of the activities. The responses listed as other durations for the tractor safety educational activities included 3-5 classes, ten days, and two weeks. When both groups were combined, 22 respondents (36.7\%) reported the activities were conducted for half a day or less, and $21(35.0 \%)$ reported the activities were conducted for one to two days. Thirteen respondents (21.7\%) reported the activities were conducted for three to four days, and four $(6.6 \%)$ reported other as the duration (see Table 4).

Table 4

Duration of Tractor Educational Activities

\begin{tabular}{lcccccc}
\hline & \multicolumn{2}{c}{ Extension } & \multicolumn{2}{c}{ Ag Teacher } & \multicolumn{2}{c}{ Total } \\
\cline { 2 - 7 } & $N$ & $\%$ & $N$ & $\%$ & $N$ & $\%$ \\
\hline Half-day or less & 15 & 75.0 & 7 & 17.5 & 22 & 36.7 \\
1-2 days & 4 & 20.0 & 17 & 42.5 & 21 & 35.0 \\
$3-4$ days & 0 & 0.0 & 13 & 32.5 & 13 & 21.7 \\
Other & 1 & 5.0 & 3 & 7.5 & 4 & 6.6 \\
Total & 20 & 100.0 & 40 & 100.0 & 60 & 100.0 \\
\hline
\end{tabular}


Individuals Who Developed the Tractor Safety Educational Activities

Respondents were asked to identify the group responsible for developing the educational activities. Fifteen (71.4\%) Extension agents reported the educational activities were developed by Extension agents. One (4.8\%) Extension agent reported the activities were developed by an agricultural educator and $12(57.1 \%)$ reported others developed the activities. The Department of Agriculture, Progressive Farmer, Farm Bureau, and West Virginia Extension Service were included among the responses for others (see Appendix D). Two (5.0\%) agricultural educators reported Extension agents developed the tractor safety educational activities. Thirty-eight educators reported the agricultural educators developed the activities, and three (7.5\%) reported others developed the activities (see Table 5). Farm Bureau, FFA, and the fire department were listed as the responses for others (see Appendix D).

Table 5

Individuals/Groups who Developed the Tractor Safety Educational Activities

\begin{tabular}{lcccccc}
\hline & \multicolumn{2}{c}{ Extension } & \multicolumn{2}{c}{ Ag Teacher } & \multicolumn{2}{c}{ Total } \\
\cline { 2 - 7 } & $N$ & $\%$ & $N$ & $\%$ & $N$ & $\%$ \\
\hline Extension & 15 & 71.4 & 2 & 5.0 & 17 & 27.9 \\
Agricultural educator & 1 & 4.8 & 38 & 95.0 & 39 & 63.9 \\
Other & 12 & 57.1 & 3 & 7.5 & 15 & 24.6 \\
\hline
\end{tabular}

Methods of Instruction for Tractor Safety Educational Activities

The three most frequently occurring methods of instruction reported by Extension agents were demonstration (85.7\%), lecture (76.2\%), and use of a real tractor (47.6\%). The three most frequently occurring methods of instruction reported by agricultural educators were lecture 
$(85.0 \%)$, use of a real tractor (77.5\%) and video (77.5\%). Over half (67.5\%) of the agricultural educators reported demonstration as a method of instruction (see Table 6).

Table 6

Methods of Instruction for Tractor Safety Educational Activities

\begin{tabular}{lcccccc}
\hline & \multicolumn{2}{c}{ Extension } & \multicolumn{2}{c}{ Ag Teacher } & \multicolumn{2}{c}{ Total } \\
\cline { 2 - 6 } & $N$ & $\%$ & $N$ & $\%$ & 5 & $\%$ \\
\hline Lecture & 16 & 76.2 & 34 & 85 & 50 & 82.0 \\
Video & 8 & 38.1 & 31 & 77.5 & 39 & 63.9 \\
Demonstration & 18 & 85.7 & 27 & 67.5 & 45 & 73.8 \\
Real tractor & 10 & 47.6 & 31 & 77.5 & 41 & 67.2 \\
Training Manual & 6 & 28.6 & 18 & 46.2 & 24 & 39.3 \\
Other & 4 & 19 & 2 & 5 & 6 & 9.8 \\
\hline
\end{tabular}

How Often Were Tractor Safety Activities Presented?

Participants were asked how often the tractor safety educational activities were presented to youth. Seventeen $(85.0 \%)$ Extension agents reported offering the educational activities once a year. Three $(15.0 \%)$ reported offering the activities two to three times a year. Twenty-seven $(67.5 \%)$ agricultural educators reported offering the activities once a year and $13(32.5 \%)$ reported offering them two to three times a year. When both groups were combined, 44 respondents (73.3\%) offered activities once a year and $16(26.7 \%)$ offered activities two to three times a year (see Table 7). 
Table 7

How Often Were Tractor Safety Activities Presented?

\begin{tabular}{lcccccc}
\hline & \multicolumn{2}{c}{ Extension } & \multicolumn{2}{c}{ Ag Teacher } & \multicolumn{2}{c}{ Total } \\
\cline { 2 - 7 } & $N$ & $\%$ & $N$ & $\%$ & $N$ & $\%$ \\
Once a year & 17 & 85.0 & 27 & 67.5 & 44 & 73.3 \\
2-3 Times a year & 3 & 15.0 & 13 & 32.5 & 16 & 26.7 \\
Total & 20 & 100.0 & 40 & 100.0 & 60 & 100.0 \\
\hline
\end{tabular}

Number of Youth Participants in the Tractor Safety Educational Activities

The respondents were asked to identify the number of youth participating in the tractor safety educational activities in the last year. Of the Extension agents five $(25.0 \%)$ reported that between one and ten youth participated in the activities. Four (20.0\%) Extension agents reported that 11-20 youth participated in the activities. Four (20.0\%) Extension agents reported that 21 30 youth participated in the activities. Two (10.0\%) Extension agents reported that 31-40 youth participated and five $(25.0 \%)$ reported that 50 or more youth participated in the activities. Two (5.3\%) agricultural educators reported that between one and ten youth participated in the activities and six (15.8\%) reported 11-20 youth participants. Ten (26.3) agricultural educators reported 21-30 youth participants and four (10.5\%) reported 31-40 youth participants. Sixteen (42.1\%) agricultural educators reported 50 or more youth participated in the tractor safety educational activities in the past year. When both groups were combined, seven respondents (12.1\%) had between one and ten youth participants and ten reported (17.2\%) reported 11-20 participants. Fourteen respondents (24.1\%) reported 21-30 youth participants and six (10.3\%) 
reported 31-40 youth participants. Twenty-one respondents (36.2\%) reported over 50 youth participants in the last year (see Table 8).

Table 8

Number of Youth Participants in Tractor Safety Educational Activities

\begin{tabular}{lcccccc}
\hline & \multicolumn{2}{c}{ Extension } & \multicolumn{2}{c}{ Ag Teacher } & \multicolumn{2}{c}{ Total } \\
\cline { 2 - 7 } & $N$ & $\%$ & $N$ & $\%$ & $N$ & $\%$ \\
\hline $1-10$ & 5 & 25.0 & 2 & 5.3 & 7 & 12.1 \\
$11-20$ & 4 & 20.0 & 6 & 15.8 & 10 & 17.2 \\
$21-30$ & 4 & 20.0 & 10 & 26.3 & 14 & 24.1 \\
$31-40$ & 2 & 10.0 & 4 & 10.5 & 6 & 10.3 \\
$41-50$ & 0 & 0 & 0 & 0 & 0 & 0 \\
50 plus & 5 & 25.0 & 16 & 42.1 & 21 & 36.2 \\
Total & 20 & 100.0 & 38 & 100.0 & 58 & 100.0 \\
\hline
\end{tabular}

Youth to Whom Tractor Educational Activities were Available

Participants were asked to whom the educational activities were available. Of the Extension agents offering tractor educational activities, $16(76.2 \%)$ provided activities to $4-\mathrm{H}$ youth, eight (38.1\%) provided activities to FFA youth, and $12(57.1 \%)$ provided activities to others. Extension agents listed children in public school system, all youth, youth on farms, livestock groups, $3^{\text {rd }}$ graders, $5^{\text {th }}$ graders, and adults as other groups to whom the educational activities were available. Of the agricultural educators offering tractor safety educational activities, six (15.0\%) provided activities to 4-H youth, 37 (92.5\%) provided activities to FFA youth, and $8(20.5 \%)$ provided activities to others. Agricultural educators listed students in 
agriculture classes, high school students, middle school students, and fourth graders as other groups to whom the activities were available (see Table 9).

Table 9

Youth to Whom Tractor Educational Activities Were Available

\begin{tabular}{lcccccc}
\hline & \multicolumn{2}{c}{ Extension } & \multicolumn{2}{c}{ Ag Teacher } & \multicolumn{2}{c}{ Total } \\
\cline { 2 - 6 } & $N$ & $\%$ & $N$ & $\%$ & $N$ & $\%$ \\
\hline 4-H Youth & 16 & 76.2 & 6 & 15.0 & 22 & 36.1 \\
FFA Youth & 8 & 38.1 & 37 & 92.5 & 45 & 73.8 \\
Other & 12 & 57.1 & 8 & 20.5 & 20 & 32.8 \\
\hline
\end{tabular}

Topics Covered in Tractor Educational Activities

Participants were asked to identify all topics covered during the tractor safety educational activities. The choices provided in the survey included tractor rollovers, passengers, seat belts, PTO, maintenance, and other. The number and percentage of Extension agents covering each of these topics were as follows: $19(90.5 \%)$ tractor rollovers, $17(81.0 \%)$ passengers, $18(85.7 \%)$ seat belts, 20 (95.2\%) PTO, nine (42.9\%) maintenance, and 2 (10.0\%) other topics. The number and percentage of agricultural educators covering each of these topics are as follows: 37 (94.9\%) tractor rollover, 37 (94.9\%) passengers, 38 (97.4\%) seat belts, $33(84.6 \%)$ maintenance, and 11 (28.2\%) other topics (see Table 10). 
Table 10

Topics Covered in Tractor Educational Activities

\begin{tabular}{|c|c|c|c|c|c|c|}
\hline & \multicolumn{2}{|c|}{ Extension } & \multicolumn{2}{|c|}{ Ag Teacher } & \multicolumn{2}{|c|}{ Total } \\
\hline & $N$ & $\%$ & $N$ & $\%$ & $N$ & $\%$ \\
\hline Tractor rollover & 19 & 90.5 & 37 & 94.9 & 56 & 91.8 \\
\hline Passengers & 17 & 81.0 & 37 & 94.9 & 54 & 88.5 \\
\hline Seat Belts & 18 & 85.7 & 38 & 97.4 & 56 & 91.8 \\
\hline PTO & 20 & 95.2 & 38 & 97.4 & 58 & 95.1 \\
\hline Maintenance & 9 & 42.9 & 33 & 84.6 & 42 & 68.9 \\
\hline Other & 2 & 10.0 & 11 & 28.2 & 14 & 23.0 \\
\hline
\end{tabular}

Effectiveness of Tractor Safety Educational Activities as Perceived by Extension Agents and Agricultural Educators

Extension Agents and agricultural educators were asked to rate the effectiveness of the tractor safety activities in which they were involved on. The choices provided were not effective, somewhat effective, and very effective. Twelve (63.2\%) Extension agents perceived the activities to be somewhat effective, and seven (36.8\%) perceived the activities to be very effective. Twenty-six (66.7\%) agricultural educators perceived the activities to be somewhat effective and 13 (33.3\%) perceived the activities to be very effective. When both groups were combined, 38 (66.5\%) perceived the activities to be very effective and (34.5\%) perceived the activities to be somewhat effective (see Table 11). 
Table 11

Effectiveness of Tractor Safety Educational Activities as Perceived by Extension Agents and Agricultural Educators

\begin{tabular}{lcccccc}
\hline & \multicolumn{2}{c}{ Extension } & \multicolumn{2}{c}{ Ag Teacher } & \multicolumn{2}{c}{ Total } \\
\cline { 2 - 7 } & $N$ & $\%$ & $N$ & $\%$ & $N$ & $\%$ \\
\hline Somewhat Effective & 12 & 63.2 & 26 & 66.7 & 38 & 65.5 \\
Very Effective & 7 & 36.8 & 13 & 33.3 & 20 & 34.5 \\
Total & 19 & 100.0 & 39 & 100.0 & 58 & 100.0 \\
\hline
\end{tabular}

Opportunities for Youth Certification on Tractor Safety

One agricultural educator reported that youth had the opportunity to receive certification during the tractor safety educational activities. One agricultural educator was unsure if certification was available to youth. Of those not offering certification $19(100.0 \%)$ were Extension agents and $38(95.0 \%)$ were agricultural educators (see Table 12).

Table 12

Certification Offered for Tractor Educational Activities

\begin{tabular}{lcccccc}
\hline & \multicolumn{2}{c}{ Extension } & \multicolumn{2}{c}{ Ag Teacher } & \multicolumn{2}{c}{ Total } \\
& $N$ & $\%$ & $N$ & $\%$ & $N$ & $\%$ \\
\cline { 2 - 6 } & 19 & 100.0 & 38 & 95.0 & 57 & 96.6 \\
Yes & 0 & 0.0 & 1 & 2.5 & 1 & 1.7 \\
Unsure & 0 & 0.0 & 1 & 2.5 & 1 & 1.7 \\
\hline
\end{tabular}


Perceived Problem of Tractor Accidents

Thirty-three (55.9\%) Extension agents believed that tractor accidents were a problem in their county, and one (1.7\%) believed tractor accidents to be somewhat of a problem. Twentythree agents (39.0\%) did not think that tractor accidents were a problem, and two (3.4\%) were unsure. Twenty-six (42.6\%) agricultural educators believed tractor accidents were a problem in their county, $34(55.7 \%)$ did not think tractor accidents were a problem, and one (1.7\%) was unsure. When both groups were combined, 67 respondents (55.8\%) believed tractor accidents were a problem, and $49(40.8 \%)$ did not believe tractor accidents were a problem. Three (2.5\%) were unsure, and one $(0.9 \%)$ believed tractor accidents were somewhat of a problem in their county (see Table 13).

Table 13

Are Tractor Accidents a Problem?

\begin{tabular}{lcccccc}
\hline & \multicolumn{2}{c}{ Extension } & \multicolumn{2}{c}{ Ag Teacher } & \multicolumn{2}{c}{ Total } \\
\cline { 2 - 7 } & $N$ & $\%$ & $N$ & $\%$ & $N$ & $\%$ \\
No & 23 & 39.0 & 26 & 42.6 & 49 & 40.8 \\
Yes & 33 & 55.9 & 34 & 55.7 & 67 & 55.8 \\
Unsure & 2 & 3.4 & 1 & 1.7 & 3 & 2.5 \\
Somewhat & 1 & 1.7 & 0 & 0.0 & 1 & 0.9 \\
Total & 59 & 100.0 & 61 & 100.0 & 120 & 100.0 \\
\hline
\end{tabular}

\section{Additional Tractor Safety Programs}

All participants were asked if they felt additional tractor safety programs were needed in their county. Forty-five (77.6\%) Extension agents thought additional tractor safety programs 
were needed and one (1.7\%) was unsure. Twelve (20.7\%) Extension agents thought additional tractor safety programs were not needed. Forty-seven (78.3\%) agricultural educators thought additional tractor safety programs were needed and one (1.7\%) was unsure. Twelve (20.0\%) agricultural educators thought tractor safety programs were not needed. When both groups were combined, 92 respondents $(78.0 \%)$ thought additional tractor safety programs were needed in their county and two (1.7\%) were unsure. Twenty-four $(20.3 \%)$ did not think that additional safety programs were needed (see Table 14).

Table 14

Are Additional Tractor Safety Programs Needed?

\begin{tabular}{lcccccc}
\hline & \multicolumn{2}{c}{ Extension } & \multicolumn{2}{c}{ Ag Teacher } & \multicolumn{2}{c}{ Total } \\
\cline { 2 - 6 } & $N$ & $\%$ & $N$ & $\%$ & $N$ & $\%$ \\
\hline No & 12 & 20.7 & 12 & 20.0 & 24 & 20.3 \\
Yes & 45 & 77.6 & 47 & 78.3 & 92 & 78.0 \\
Unsure & 1 & 1.7 & 1 & 1.7 & 2 & 1.7 \\
Total & 58 & 100.0 & 60 & 100.0 & 118 & 100.0 \\
\hline
\end{tabular}

\section{ATV Safety Educational Activities}

The second half of the survey contained questions regarding ATV safety educational activities offered to youth in West Virginia. Twenty (33.3\%) of the Extension agents respondents offered educational activities to youth that included ATV safety. Twelve (19.7\%) of the agricultural educators respondents offer to youth educational activities that included ATV safety. When both groups were combined, 32 respondents (26.4\%) offer ATV safety activities to youth (see Table 15). 
Table 15

ATV Educational Activities Provided by Extension Agents and Agricultural Education Teachers

\begin{tabular}{lrrrrrr}
\hline & \multicolumn{2}{c}{ Extension } & \multicolumn{2}{c}{ Ag Teacher } & \multicolumn{2}{c}{ Total } \\
\cline { 2 - 7 } & $\mathrm{N}$ & $\%$ & $\mathrm{~N}$ & $\%$ & $\mathrm{~N}$ & $\%$ \\
\hline Yes & 20 & 33.3 & 12 & 19.7 & 32 & 26.4 \\
No & 40 & 66.7 & 49 & 80.3 & 89 & 73.6 \\
Total & 60 & 100.0 & 61 & 100.0 & 121 & 100.0 \\
\hline
\end{tabular}

\section{Target Ages of ATV Educational Activities}

Extension agents and agricultural educators were asked to identify all age groups that were targeted for the ATV educational activities. Five (25.0\%) Extension agents targeted youth less than eight years of age. Eighteen (90.0\%) targeted youth eight to eleven years of age. Fourteen $(70.0 \%)$ targeted youth $12-14$ years of age. Eleven $(55.0 \%)$ targeted youth $15-17$ years of age, and seven (35.0\%) targeted persons 18 years of age or older. Of the agricultural educators, five (45.5\%) targeted youth eight to eleven years of age. Eight (72.7\%) teachers targeted youth 12-14 years of age and eight (72.7\%) targeted youth $15-17$ years of age. Two $(18.2 \%)$ targeted persons 18 years of age and older. The two groups targeted the most by agricultural educators were youth 12-14 years of age and 15-17 years of age (see Table 16). This is consistent with the ages that secondary agricultural educators have the most contact with in middle and high schools. 
Table 16

Target Ages of ATV Educational Activities Provided by Extension Agents and Agricultural educators

\begin{tabular}{lcccccc}
\hline & \multicolumn{2}{c}{ Extension } & \multicolumn{2}{c}{ Ag Teacher } & \multicolumn{2}{c}{ Total } \\
\hline & $N$ & $\%$ & $N$ & $\%$ & $N$ & $\%$ \\
\hline$<8$ year olds & 5 & 25.0 & 0 & 0 & 5 & 16.1 \\
$8-11$ & 18 & 90.0 & 5 & 45.5 & 23 & 74.2 \\
$12-14$ & 14 & 70.0 & 8 & 72.7 & 22 & 71.0 \\
$15-17$ & 11 & 55.0 & 8 & 72.7 & 19 & 61.3 \\
18 or older & 7 & 35.0 & 2 & 18.2 & 9 & 29.0 \\
\hline
\end{tabular}

Individuals who Conducted the ATV Safety Educational Activities

Participants were asked to identify who conducted the ATV educational activities. Of the Extension agents, five $(26.3 \%)$ did not respond to the question. Twelve (63.2\%) responded that Extension agents conducted the ATV safety educational activities. Two (10.5\%) responded that both an Extension agent and agricultural educator conducted the activities. Of the agricultural educators, eight $(80.0 \%)$ responded that an agricultural educator conducted the activities and two (20.0\%) responded both an Extension agent and agricultural educator conducted the activities (see Table 17). Sixteen individuals from both groups chose others as having conducted the ATV safety educational activities. Twelve were Extension agents and four were agricultural educators. The responses listed for others who conducted the ATV safety educational activities included: Progressive Farmer Farm Safety Day Camp instructors, Farm Bureau, ATV sales 
representative, trained ATV specialist, West Virginia Department of Agriculture, FFA students, 4-H club leaders, and county sheriff's department (see Appendix D).

Table 17

Individuals who Conducted ATV Educational Activities

\begin{tabular}{lcccccc}
\hline & \multicolumn{2}{c}{ Extension } & \multicolumn{2}{c}{ Ag Teacher } & \multicolumn{2}{c}{ Total } \\
\cline { 2 - 6 } & $N$ & $\%$ & $N$ & $\%$ & $N$ & $\%$ \\
\hline No Answer & 5 & 26.3 & 0 & 0.0 & 5 & 17.2 \\
Extension Agent & 12 & 63.2 & 0 & 0.0 & 12 & 41.4 \\
Agriculture Teacher & 0 & 0.0 & 8 & 80.0 & 8 & 27.6 \\
Both Extension and Ag & 2 & 10.5 & 2 & 20.0 & 4 & 13.8 \\
Teacher & & & & & \\
Total & 19 & 100.0 & 10 & 100.0 & 29 & 100.0 \\
\hline
\end{tabular}

Duration of ATV Educational Activities

Sixteen (80.0\%) Extension agents reported that the ATV safety education activities were conducted for half a day or less. Three $(15.0 \%)$ reported that the activities were conducted for one to two days, and one (5.0\%) reported other as the duration of the ATV safety educational activities. The duration listed for other was one hour. Five (45.5\%) agricultural educators reported that the activities were conducted for half a day or less. Five (45.5\%) agricultural educators reported that the activities were conducted for one to two days, and one $(9.0 \%)$ reported other as the duration of the activities. The duration listed for other was one to three class periods. Of both groups $21(67.7 \% 0$ offered the activities for one half day or less. Eight 
$(25.8 \%)$ offered the activities for one to two days and two $(6.5 \%)$ offered the activities for other durations (see Table 18).

Table 18

Duration of ATV Educational Activities

\begin{tabular}{lcccccc}
\hline & \multicolumn{2}{c}{ Extension } & \multicolumn{2}{c}{ Ag Teacher } & \multicolumn{2}{c}{ Total } \\
\cline { 2 - 6 } & $N$ & $\%$ & $N$ & $\%$ & $N$ & $\%$ \\
\hline Half-day or less & 16 & 80.0 & 5 & 45.5 & 21 & 67.7 \\
$1-2$ days & 3 & 15.0 & 5 & 45.5 & 8 & 25.8 \\
Other & 1 & 5.0 & 1 & 9.0 & 2 & 6.5 \\
Total & 20 & 100.0 & 11 & 100.0 & 31 & 100.0 \\
\hline
\end{tabular}

Individuals Who Developed the ATV Safety Educational Activities

Participants were asked to mark all individuals who developed the ATV safety educational activities. Choices provided were Extension agent, agricultural educator, and other with an open-ended response. Eleven (57.9\%) Extension agents reported the educational activities were developed by Extension agents. One (5.3\%) Extension agent reported that the activities were developed by an agricultural educator, and $13(68.4 \%)$ reported other individuals developed the activities. Extension agents listed the FBI, Progressive Framer, Farm Bureau, West Virginia Department of Agriculture, West Virginia University Safety and Health Division, and ATV manufacturers as others who helped develop the activities (see Appendix D). Two $(18.2 \%)$ of the agricultural educators reported that Extension agents developed the tractor safety educational activities. Nine (81.8\%) reported the agricultural educators developed the activities, and three (27.3\%) reported others as having developed the activities (see Table 19). Agricultural 
educators listed Progressive Farmer, Farm Bureau, and the FFA as others who helped develop the activities (see Appendix D).

Table 19

Individuals Who Developed the ATV Safety Educational Activities

\begin{tabular}{lcccccc}
\hline & \multicolumn{2}{c}{ Extension } & \multicolumn{2}{c}{ Ag Teacher } & \multicolumn{2}{c}{ Total } \\
\cline { 2 - 7 } & $N$ & $\%$ & $N$ & $\%$ & $N$ & $\%$ \\
\hline Extension & 11 & 57.9 & 2 & 18.2 & 13 & 43.3 \\
Ag Teacher & 1 & 5.3 & 9 & 81.8 & 10 & 33.3 \\
Other & 13 & 68.4 & 3 & 27.3 & 16 & 53.3 \\
\hline
\end{tabular}

Methods of Instruction for ATV Safety Educational Activities

The three most frequently occurring methods of instruction reported by Extension agents were use of a real ATV (85.0\%), demonstration (75.0\%), and lecture (65.0\%). Over half $(60.0 \%)$ also reported using video as a method of instruction. The three most frequently occurring methods of instruction reported by agricultural educators were lecture (81.8\%), video (72.7\%), and demonstration (72.7\%). Over half (54.5) of the agricultural educators reported using a training manual as a method of instruction (see Table 20). 
Table 20

Methods of Instruction for ATV Safety Educational Activities

\begin{tabular}{lcccccc}
\hline & \multicolumn{2}{c}{ Extension } & \multicolumn{2}{l}{ Ag Teacher } & \multicolumn{2}{c}{ Total } \\
\cline { 2 - 7 } & $N$ & $\%$ & $N$ & $\%$ & $N$ & $\%$ \\
\hline Lecture & 13 & 65.0 & 9 & 81.8 & 22 & 71.0 \\
Video & 12 & 60.0 & 8 & 72.7 & 20 & 64.5 \\
Demonstration & 15 & 75.0 & 8 & 72.7 & 23 & 74.2 \\
Real ATV & 17 & 85.0 & 5 & 45.5 & 22 & 71.0 \\
Training manual & 3 & 15.0 & 6 & 54.5 & 9 & 29.0 \\
Other & 3 & 15.0 & 1 & 9.1 & 4 & 12.9 \\
\hline
\end{tabular}

How often Were ATV Safety Activities Presented?

Participants were asked how often the tractor safety educational activities were presented to youth. Eighteen (100.0\%) Extension agents reported offering the activities once a year. Eight (72.7\%) agricultural educators reported offering the activities once a year and three (27.3\%) reported offering them two to three times a year. When both groups were combined, 26 respondents $(89.7 \%)$ offered activities once a year and three (10.3\%) offered activities two to three times a year (see Table 21). 
Table 21

How Often Were ATV Safety Activities Presented?

\begin{tabular}{lcccccc}
\hline & \multicolumn{2}{c}{ Extension } & \multicolumn{2}{c}{ Ag Teacher } & \multicolumn{2}{c}{ Total } \\
\cline { 2 - 6 } & $N$ & $\%$ & $N$ & $\%$ & $N$ & $\%$ \\
\hline Once a year & 18 & 100.0 & 8 & 72.7 & 26 & 89.7 \\
2-3 Times a year & 0 & 0.0 & 3 & 27.3 & 3 & 10.3 \\
Total & 18 & 100.0 & 11 & 100.0 & 29 & 100.0 \\
\hline
\end{tabular}

Number of Youth Participants in the ATV Safety Educational Activities

The participants were asked to identify the number of youth participating in the ATV safety educational activities in the last year. One (5.9\%) Extension agent reported that between one and ten youth participated in the activities. Two (11.8\%) Extension agents reported that 1120 youth participated in the activities. Three (17.6\%) Extension agents reported that $21-30$ youth participated in the activities. Two (11.8\%) Extension agents reported that 31-40 youth participated and $9(52.9 \%)$ reported that more than 50 youth participated in the activities. Two (18.2\%) agricultural educators reported that 11-20 youth participated in the activities, and two (18.2\%) agricultural educators reported that $21-30$ youth participated in the activities. One (9.1\%) agricultural educator reported that $31-40$ youth participated in the activities and six (54.5\%) reported that more than 50 youth participated in the activities. From both groups one (3.6\%) reported between one and ten youth participants. Four (14.3\%) reported 11-20 youth participants. Five (17.8\%) reported 21-30 youth participants. Three (10.7\%) reported 31-40 youth participants, and $15(53.6 \%)$ reported more than 50 participants in the ATV safety educational activities during the past year (see Table 22). 
Table 22

Number of Youth Participants in ATV Safety Educational Activities

\begin{tabular}{lcccccc}
\hline & \multicolumn{2}{c}{ Extension } & \multicolumn{2}{c}{ Ag Teacher } & \multicolumn{2}{c}{ Total } \\
\cline { 2 - 7 } & $N$ & $\%$ & $N$ & $\%$ & $N$ & $\%$ \\
\hline $1-10$ & 1 & 5.9 & 0 & 0.0 & 1 & 3.6 \\
$11-20$ & 2 & 11.8 & 2 & 18.2 & 4 & 14.3 \\
$21-30$ & 3 & 17.6 & 2 & 18.2 & 5 & 17.8 \\
$31-40$ & 2 & 11.8 & 1 & 9.1 & 3 & 10.7 \\
$41-50$ & 0 & 0 & 0 & 0 & 0 & 0 \\
50 plus & 9 & 52.9 & 6 & 54.5 & 15 & 53.6 \\
Total & 17 & 100.0 & 11 & 100.0 & 28 & 100.0 \\
\hline
\end{tabular}

Youth to Whom ATV Educational Activities were Available

Participants were asked to whom the educational activities were available. Of the Extension agents offering ATV educational activities, 13 (65.0\%) provided activities to 4-H youth, five (25.0\%) provided activities to FFA youth, and ten (50.0\%) provided activities to others. Extension agents listed all youth, school students, third graders, fourth graders, fifth graders, and elementary school students, adults, and the general public as other groups to whom the educational activities were available (see Appendix D). Of the agricultural educators offering ATV safety educational activities three (27.3\%) provided activities to 4-H youth, eight (72.7\%) provided activities to FFA youth and five (50.0\%) provided activities to others (see Table 23). Agricultural educators listed school students, fourth graders, sixth graders, eighth 
graders, and middle school students as other groups to whom the activities were available (see Appendix D).

Table 23

Youth to Whom ATV Educational Activities were Available

\begin{tabular}{lcccccc}
\hline & \multicolumn{2}{c}{ Extension } & \multicolumn{2}{c}{ Ag Teacher } & \multicolumn{2}{c}{ Total } \\
\cline { 2 - 7 } & $N$ & $\%$ & $N$ & $\%$ & $N$ & $\%$ \\
\hline 4-H Youth & 13 & 65.0 & 3 & 27.3 & 16 & 51.6 \\
FFA Youth & 5 & 25.0 & 8 & 72.7 & 13 & 41.9 \\
Other & 10 & 50.0 & 5 & 50.0 & 15 & 50.0 \\
\hline
\end{tabular}

\section{Topics Covered in ATV Educational Activities}

Participants were asked to identify all topics covered during the ATV safety educational activities. The choices provided in the survey included helmet use, passengers, paved roads, maintenance, rider dynamics, laws, and other. The number and percentage of Extension agents covering each of these topics were: helmet use, 19 respondents (100.0\%); passengers, 18 respondents (94.7\%); paved roads, 17 respondents (89.5\%); maintenance, five respondents (26.3\%); rider dynamics, 19 respondents (100.0\%); laws, 15 respondents $(78.9 \%)$; and other, one respondent (19.3\%). The number and percentage of agricultural educators covering each of these topics are as follows: helmet use, ten respondents (90.9\%); passengers, 11 respondents (100.0\%); paved roads, seven respondents (63.6\%); maintenance, seven respondents (63.6\%); rider dynamics, nine respondents (81.8\%); and laws, eight respondents (80.1\%) (see Table 24$)$. 
Table 24

Topics Covered in ATV Educational Activities

\begin{tabular}{|c|c|c|c|c|c|c|}
\hline & \multicolumn{2}{|c|}{ Extension } & \multicolumn{2}{|c|}{ Ag Teacher } & \multicolumn{2}{|c|}{ Total } \\
\hline & $N$ & $\%$ & $N$ & $\%$ & $N$ & $\%$ \\
\hline Helmet Use & 19 & 100.0 & 10 & 90.9 & 29 & 96.7 \\
\hline Passengers & 18 & 94.7 & 11 & 100.0 & 29 & 96.7 \\
\hline Paved Roads & 17 & 89.5 & 7 & 63.6 & 24 & 80.0 \\
\hline Maintenance & 5 & 26.3 & 7 & 63.6 & 12 & 40.0 \\
\hline Rider Dynamics & 19 & 100.0 & 9 & 81.8 & 28 & 93.3 \\
\hline Laws & 15 & 78.9 & 8 & 80.0 & 23 & 79.3 \\
\hline Other & 1 & 5.3 & 0 & 0 & 1 & 3.3 \\
\hline
\end{tabular}

Effectiveness of ATV Safety Educational Activities as Perceived by Extension Agents and Agricultural Educators

Extension Agents and agricultural educators were asked to rate the effectiveness of the ATV safety activities in which they were involved on. The choices provided were not effective, somewhat effective, and very effective. Eleven (68.75\%) Extension agents perceived the activities to be somewhat effective, and three (18.75\%) perceived the activities to be very effective. Two (12.5\%) Extension agents were unsure of the effectiveness of the ATV safety educational activities. Seven (63.6\%) agricultural educators perceived the activities to be somewhat effective, and three (27.3\%) perceived the activities to be very effective. One (7.1\%) agricultural educator felt the activities were not effective. When both groups were combined, six respondents $(22.2 \%)$ perceived the activities to be very effective, $18(66.7 \%)$ perceived the 
activities to be somewhat effective, and one (3.7\%) felt the activities were not effective (see Table 25).

Table 25

Effectiveness of ATV Safety Educational Activities as Perceived by Extension Agents and Agricultural Educators

\begin{tabular}{lcccccc}
\hline & \multicolumn{2}{c}{ Extension } & \multicolumn{2}{c}{ Ag Teacher } & \multicolumn{2}{c}{ Total } \\
\cline { 2 - 6 } & $N$ & $\%$ & $N$ & $\%$ & $N$ & $\%$ \\
\hline Not Effective & 0 & 0 & 1 & 9.1 & 1 & 3.7 \\
Somewhat Effective & 11 & 68.75 & 7 & 63.6 & 18 & 66.7 \\
Very Effective & 3 & 18.75 & 3 & 27.3 & 6 & 22.2 \\
Unsure & 2 & 12.5 & 0 & 0 & 2 & 7.4 \\
Total & 16 & 100.0 & 11 & 100.0 & 27 & 100.0 \\
\hline
\end{tabular}

Perceived Problem of ATV Accidents

Fifty-five (91.7\%) Extension agents believed that ATV accidents were a problem in their county and five $(8.3 \%)$ did not think that ATV accidents were a problem. Fifty-three $(89.8 \%)$ agricultural educators believed ATV accidents were a problem in their county, five $(8.5 \%)$ did not think ATV accidents were a problem, and one (1.7\%) was unsure. When both groups were combined, 108 respondents $(90.8 \%)$ believed ATV accidents were a problem, ten $(48.4 \%)$ did not believe ATV accidents were a problem, and one (2.5\%) was unsure (see Table 26). 
Table 26

Are ATV Accidents Perceived as a Problem?

\begin{tabular}{lcccccc}
\hline & \multicolumn{2}{c}{ Extension } & \multicolumn{2}{c}{ Ag Teacher } & \multicolumn{2}{c}{ Total } \\
\cline { 2 - 7 } & $N$ & $\%$ & $N$ & $\%$ & $N$ & $\%$ \\
\hline No & 5 & 8.3 & 5 & 8.5 & 10 & 8.4 \\
Yes & 55 & 91.7 & 53 & 89.8 & 108 & 90.8 \\
Unsure & 0 & 0 & 1 & 1.7 & 1 & 0.8 \\
Total & 60 & 100.0 & 59 & 100.0 & 119 & 100.0 \\
\hline
\end{tabular}

Main Types of ATV Accidents

Participants were asked to identify in their perception the main type of ATV accidents in their county. Choices given in the survey were agricultural use or recreational use. One Extension agent (1.7\%) reported agricultural use and 58 (98.3\%) Extension agents reported recreational use as the main type of ATV accidents in their county. Two (3.3\%) agricultural educators reported agricultural use and 58 (96.7\%) reported recreational use as the main type of ATV accident in their county. Of both groups three respondents (2.5\%) reported agricultural use as the main type of ATV accident and $116(97.5 \%)$ reported recreational use as the main type of ATV accident (see Table 27). 
Table 27

Main types of ATV Accidents

\begin{tabular}{lcccccc}
\hline & \multicolumn{2}{c}{ Extension } & \multicolumn{2}{c}{ Ag Teacher } & \multicolumn{2}{c}{ Total } \\
\cline { 2 - 6 } & $N$ & $\%$ & $N$ & $\%$ & $N$ & $\%$ \\
\hline Agricultural Use & 1 & 1.7 & 2 & 3.3 & 3 & 2.5 \\
Recreational Use & 58 & 98.3 & 58 & 96.7 & 116 & 97.5 \\
Total & 59 & 100.0 & 60 & 100.0 & 119 & 100.0 \\
\hline
\end{tabular}

Additional ATV Safety Programs

Survey participants were asked if they thought additional ATV safety programs were needed in their county. Of the Extension agents, $55(91.7 \%)$ thought additional ATV safety programs were needed and five $(8.3 \%)$ did not believe additional ATV safety programs were needed. Of the agricultural educators, 53 (89.7\%) thought additional safety programs were need, five $(8.5 \%)$ did not think additional safety programs were needed, and one (1.7\%) agricultural educator was unsure. When both groups were combined, $108(90.8 \%)$ thought additional programs were needed, while ten $(8.4 \%)$ did not think additional programs were needed, and one $(0.8 \%)$ was unsure (see Table 28$)$. 
Table 28

Are Additional ATV Safety Programs Needed?

\begin{tabular}{lcccccc}
\hline & \multicolumn{2}{c}{ Extension } & \multicolumn{2}{c}{ Ag Teacher } & \multicolumn{2}{c}{ Total } \\
\cline { 2 - 6 } & $N$ & $\%$ & $N$ & $\%$ & $N$ & $\%$ \\
\hline No & 1 & 1.7 & 3 & 4.8 & 4 & 3.3 \\
Yes & 57 & 96.6 & 58 & 93.6 & 115 & 95.0 \\
Unsure & 1 & 1.7 & 1 & 1.6 & 2 & 1.7 \\
Total & 59 & 100.0 & 62 & 100.0 & 121 & 100.0 \\
\hline
\end{tabular}




\title{
CHAPTER V
}

\author{
Summary, Conclusions, and Recommendations
}

Purpose of the Study

The purpose of the study was to identify the number and types of tractor and ATV safety programs available to youth in West Virginia through the Extension Service and secondary agricultural education programs. This information will be useful to safety professionals and educators in planning additional safety programs for youth in West Virginia.

Objectives of the Study

The primary objective of the research was to identify tractor and ATV safety programs available to youth in West Virginia through the Extension service and secondary agricultural education programs.

Secondary objectives included:

1. Identify the number of tractor and ATV safety programs available to youth in West Virginia through the Extension Service and secondary agricultural education teachers.

2. Determine the types of safety programs available to youth in West Virginia through the Extension Service and secondary agricultural education programs.

3. Determine how often these programs are offered.

4. Determine the perceptions of Extension Agents and secondary agricultural teachers toward these programs.

\section{Research Questions}

1. How many secondary agricultural educators and Extension agents offer tractor safety educational activities to youth in West Virginia? 
2. What age groups were targeted by the tractor safety educational activities offered by the agricultural educators and Extension agents?

3. What topics were covered in the tractor safety educational activities?

4. What methods of instruction were utilized during the tractor safety educational activities?

5. Did agricultural educators and Extension agents feel that tractor accidents are a problem in their county?

6. Did agricultural educators and Extension agents feel that more tractor safety programs are needed in their county?

7. How many secondary agricultural educators and Extension agents offer ATV safety educational activities to youth in West Virginia?

8. What age groups were targeted by the ATV safety educational activities offered by the agricultural educators and Extension agents?

9. What topics were covered in the ATV safety educational activities?

10. What methods of instruction were utilized during the ATV safety educational activities?

11. Did agricultural educators and Extension agents feel that ATV accidents are a problem in their county?

12. Did agricultural educators and Extension agents feel the main cause of ATV accidents is agricultural or recreational use?

13. Did agricultural educators and Extension agents feel that more ATV safety programs are needed in their county? 


\section{Summary}

The accessible population for the study consisted of 185 agricultural educators and Extension agents employed in West Virginia during the winter of 2003-2004. One hundred twenty-three of the 185 surveys were returned with usable data resulting in a $66 \%$ response rate. Of the total 123 respondents, 62 (50.4\%) were secondary agricultural educators and $61(49.6 \%)$ were extension agents. Over half $(64.5 \%)$ of the agricultural educators offered educational activities to youth that included tractor safety. Less than half (35\%) Extension agents offered educational activities to youth that included tractor safety. When both groups were combined, half $(50.0 \%)$ offered tractor safety educational activities.

The age groups targeted most by Extension agents for tractor safety educational activities were youth eight to eleven years of age (71.4\%), 12 -14 years of age (66.7\%), and 15-17 years of age $(57.1 \%)$. The age groups targeted most by agricultural educators for tractor safety educational activities were youth $15-17$ years of age (92.5\%) and $12-14$ years of age (42.5\%). This is consistent with the age groups secondary agricultural educators have the most contact with during the school year. The three most frequently occurring methods of instruction reported by Extension agents were demonstration (85.7\%), lecture $(76.2 \%)$, and use of a real tractor (47.6\%). The three most frequently occurring methods of instruction reported by agricultural educators were lecture $(85.0 \%)$, use of a real tractor $(77.5 \%)$ and video $(77.5 \%)$. Over half of the agricultural educators $(67.5 \%)$ also reported demonstration as a method of instruction.

Seventy-three percent of all tractor safety educational activities provided by Extension agents and agricultural educators were offered once a year. The topics covered most frequently by Extension agents included tractor rollovers $(90.5 \%)$, PTO $(95.2 \%)$, seat belts $(85.7 \%)$, and passengers $(81.0 \%)$. The topics covered the most frequently by agricultural educators included 
seat belts (97.4\%), PTO (97.4\%), tractor rollovers (94.9\%), and passengers $(94.9 \%)$. Sixty-five percent of the combined groups felt the tractor safety educational activities were somewhat effective and $34.5 \%$ felt they were very effective. Of both groups, one agricultural educator $(1.7 \%)$ offered certification during they tractor safety educational activities. Over half (55.8\%) felt tractor accidents were a problem in their county, and 78\% thought additional safety programs were needed.

Less than half (33.3\%) of Extension agents offered educational activities to youth that included ATV safety. Less than one fifth of the agricultural educators (19.7\%) offered educational activities to youth that included ATV safety. When both groups were combined, $26.4 \%$ offered ATV safety educational activities.

The age groups targeted most by Extension agents for ATV safety educational activities were youth eight to eleven years of age (90.0\%), 12 -14 years of age (70.0\%), and 15-17 years of age (55.0\%). The age groups targeted most by agricultural educators for ATV safety educational activities were youth $12-14$ years of age $(72.7 \%)$ and $15-17$ years of age $(72.7 \%)$. This is also consistent with the age groups secondary agricultural educators have the most contact with during the school year. The three most frequently occurring methods of instruction reported by Extension agents were use of a real ATV (85.0\%), demonstration (75.0\%), and lecture (65.0\%). Over half (60.0\%) also reported using video as a method of instruction. The three most frequently occurring methods of instruction reported by agricultural educators were lecture $(81.8 \%)$, video $(72.7 \%)$, and demonstration $(72.7 \%)$. Over half $(54.5)$ of the agricultural educators reported using a training manual as a method of instruction.

Of all ATV safety educational activities provided by Extension agents and agricultural educators $89.7 \%$ were offered once a year. The topics covered most frequently by Extension 
agents included rider dynamics (100.0\%), helmet use (100.0\%), passengers (94.7\%), and paved roads $(89.5 \%)$. The topics covered the most frequently by agricultural educators included passengers $(100.0 \%)$, helmet use $(90.9 \%)$, rider dynamics $(81.8 \%)$, and laws $(80.0 \%)$. When both groups were combined, $66.7 \%$ felt the ATV safety educational activities were somewhat effective, $27.3 \%$ felt they were very effective, and 3.7\% felt they were not effective. Most (90.8\%) felt ATV accidents were a problem in their county, and 95.0\% thought additional safety programs were needed. One hundred sixteen (97.5\%) agricultural educators and Extension agents felt recreational ATV use was the main cause of ATV accidents.

\section{Conclusions}

Based upon the results of the study the following conclusions were drawn:

1. The majority of Extension agents and agricultural educators felt tractor accidents were a problem in their county.

2. Approximately one half of agricultural teachers and Extension agents offered tractor safety educational activities to youth in West Virginia.

3. Instructors used a variety of techniques, including demonstration, lecture, video, and the use of a real tractor to educate youth about tractor safety.

4. Instructors routinely included topics such as PTOs, tractor rollovers, seat belts, and passengers in their instructional program.

5. All of the instructors indicated the tractor safety educational activities had some level of effectiveness.

6. An overwhelming majority of the respondents thought additional tractor safety educational activities were needed. 
7. A significant number of Extension agents and agricultural educators felt ATV accidents were a problem in their county.

8. A majority of Extension agents and agricultural educators did not offer ATV safety educational activities to youth.

9. For those individuals who offered ATV safety educational activities, the learning activities included the use of a real ATV, demonstrations, and lectures, and videos.

10. Instructors were most likely to cover rider dynamics, helmet use, passengers, laws, and use on paved roads during ATV safety educational activities.

11. An overwhelming majority of the respondents felt the ATV safety educational activities were effective.

12. An overwhelming majority of Extension agents and agricultural educators felt recreational ATV use was the main type of ATV accidents.

13. Most Extension agents and agricultural educators felt additional ATV safety programs were needed in their county.

\section{Recommendations}

Based upon the review of literature and results of the study the following recommendations are proposed by the researcher:

1. Further research should be conducted to determine if individuals or groups other than Extension agents and agricultural educators offer tractor/ATV safety programs to youth in West Virginia.

2. Further research should be conducted to determine the effectiveness of the tractor/ATV programs that have been offered to youth in West Virginia. 
3. Extension agents and agricultural educators should be aware of and implement the resources available (existing programs, training materials, safety specialists).

4. Extension agents and agricultural educators should collaborate to provide more adequate programs on tractor/ATV safety to youth in West Virginia.

5. Extension agents and agricultural educators should collaborate to target more youth for tractor/ATV safety programs in West Virginia. 


\section{REFERENCES}

Ambe, F., Bruening, T. H., \& Murphy, D. J. (1994). Tractor operator's perceptions of farm tractor safety issues and implications to agricultural and extension education. Journal of Agricultural Education,35(4), 67-73.

Anderson, M. \& Magleby, R. (1997). Agriculture Handbook No. 712 Agriculture Resources and Environmental Indicators, 1996 - 1997, 143. Retrieved April 5, 2004 from http://ers.usda.gov/publications/arei/arei2001

Carraba, J. J., Talbert, A. B., Field, W. E., \& Tormoehlen, R. (2001). Effectiveness of the Indiana 4-H tractor program: alumni perceptions. Journal of Agricultural Education, $34(3), 11-20$.

Center for Rural and Emergency Medicine. (2002a). Tractor related deaths among WV farmers: January 1997-August 2002. West Virginia University: Morgantown, WV

Center for Rural and Emergency Medicine. (2002b). West Virginia ATV deaths: 2000-2002. West Virginia University. Morgantown, WV.

Dillman, D. (1978). Mail and telephone surveys: The total design method. New York, NY: John Wiley and Sons.

Kaplin. P. S. (1991). A child's odyssey, $2^{\text {nd }}$ edition. St. Paul, MN: West Publishing Co.

Karlson, T. \& Noren, J. (1979). Farm tractor fatalities: the failure of voluntary safety standards. Journal of Environmental Health 69(2), 146-149.

Kelsey, T.W. (1991, October). Fatal farm accidents in New York: Estimates of their costs. Northeast Journal of Agricultural Economics.

Lee, B., Gallagher, S., Marlenga, B., \& Hard, D. (2002). Child agricultural injury prevention: progress report and updated national action plan from the 2001 summit. Marshfield, WI: Marshfield Clinic.

National Children's Center for Rural \& Agricultural Health \& Safety. (2000). All-terrain vehicle safety: fact sheet. Marshfield, WI: Marshfield Clinic. Retrieved October 28, 2002 from http://www.research.marshfieldclinic.orgh/children/Resources/ATV/Factsheet.htm.

National Children's Center for Rural \& Agricultural Health \& Safety. (2002a). Fact sheet: Agriculture safety and children. Marshfield, WI: Marshfield Clinic. Retrieved October 28,2002 from http://www.research.marshfieldclinic.org/children/Resources/Agriculture/FactSheet.htm.

National Children's Center for Rural \& Agricultural Health \& Safety. (2002b). Brief summary of public policy relating to childhood agriculture labor. Marshfield, WI: Marshfield Clinic. 
Retrieved October 28, 2002 from

http://www.research.marshfieldclinic.org/children/Resources/Agriculture/PublicPolicy.ht $\mathrm{m}$.

National Safety Council. (1992). Accident facts: 1992 edition. Chicago: National Safety Council.

National Safety Council. (2001). Agricultural safety: National Safety Council policy statement on childhood risks involving tractors. Chicago: National Safety Council. Retrieved October 29, 2002 from http://www.nsc.org/issues/agri/policy/htm.

New York Center for Agricultural Medicine and Health. (2002). Tractors, the number 1 cause of fatalities on the farm. National Ag Safety Database. Retrieved October 28, 2002 from http://www.cdc.gov.nasd/docs/htm.

Robinson, J. P., Shaver, P. R., \& Wrightsman, L. S. (1991). Criteria for scale selection and evaluation. In J.P. Robinson, P. R. Shaver, \& L. S. Wrightsman (Eds.). Measures of personality and social psychological attitudes (pp.1-16). New York: Academic Press.

Stoskopf, C. H., \& Venn, J. (1985). Farm accidents and injuries: A review and ideas for prevention. Journal of Environmental Health, 47(5), 250-252.

U.S. Department of Health \& Human Service. (1996). Trac-safe: A community based program for reducing injuries and deaths due to tractor overturns: facilitator's manual. U.S. Department of Health \& Human Service, National Institute for Occupational Safety \& Health: Cincinnati, Ohio.

U.S. Census Bureau. (April 2003). State and county quick facts. Retrieved November 3, 2003 from http://www.quickfacts.census.gov/qfd/states/54/54027.html.

U.S. Department of Labor. (1995). Farm safety. (Fact Sheet No. OSHA 95-39). Occupational Safety \& Health Administration: Washington, D.C.

Zink, C. L. (1999). Early Development of Farm Safety: A Brief History of the National Institute for Farm Safety. Retrieved October 1, 2002 from http://www.ag.ohiostate.edu/ agsafety/NIF/historyc.htm. 
APPENDICES 
APPENDIX A

Cover Letter 
September 8, 2003

«ATFirst_Name» «ATLast_Name»

«ATH_Address»

«ATH_City», «ATH_State» «ATH_Zip»

Dear «Sal» «ATLast_Name»:

It is important to recognize and understand the unique health and safety issues of youth in agriculture. There are 20,000 farms in West Virginia and nearly 4 million acres of farmland. Children are at special risk of farm-related accidents because they live, work, and play around potential agricultural hazards. The tractor is involved in over half of all farm accidents. Another agent of serious accidents to youth is All-terrain vehicles (ATVs). West Virginia leads the nation in ATV-related deaths.

I am conducting a research study to determine the number and types of tractor and ATV safety programs available to youth in West Virginia. The results of this survey will be used to prepare a thesis to partially fulfill the requirements for a Master of Science Degree in Agricultural Education at West Virginia University. The results of this study will be useful to safety professionals and educators in planning and improving safety programs for youth.

Please take a few minutes and complete the enclosed questionnaire. Although your participation is voluntary, your input is vital to the success of this study. Feel free to leave any question blank that you are not comfortable answering. All responses will be held as confidential as possible. The results will be reported in summary format and, individual responses will not be identifiable. At the top right corner of the first page you will notice a code. This code is for identifying nonrespondents for follow-up and will be destroyed before the data are analyzed.

For your convenience, a postage-paid, self-addressed envelope is provided. Your participation by completing and returning the questionnaire by September 26, 2003 is greatly appreciated. Thank you in advance for your cooperation.

Sincerely,

Renee D. Chambers

Graduate Student
Harry N. Boone, Jr., Ph.D.

Assistant Professor 
APPENDIX B

Follow-Up Cover Letter 
October 3,2003

«ATFirst Name» «ATLast Name»

«ATH_Address»

«ATH_City», «ATH_State» «ATH_Zip»

Dear «Sal» «ATLast_Name»:

On September $8^{\text {th }}$, I mailed you a questionnaire about the number and types of tractor and ATV safety programs available to youth in West Virginia. As of today I have not received your response. Your information is vital to the success of this research effort and protecting the safety of West Virginia's youth.

It is important to recognize and understand the unique health and safety issues of youth in agriculture. There are 20,000 farms in West Virginia and nearly 4 million acres of farmland. Children are at special risk of farm-related accidents because they live, work, and play around potential agricultural hazards. The tractor is involved in over half of all farm accidents. Another agent of serious accidents to youth is All-terrain vehicles (ATVs). West Virginia leads the nation in ATV-related deaths.

I am conducting a research study to determine the number and types of tractor and ATV safety programs available to youth in West Virginia. The results of this survey will be used to prepare a thesis to partially fulfill the requirements for a Master of Science Degree in Agricultural Education at West Virginia University. The results of this study will be useful to safety professionals and educators in planning and improving safety programs for youth.

Please take a few minutes and complete the enclosed questionnaire. Although your participation is voluntary, your input is vital to the success of this study. Feel free to leave any question blank that you are not comfortable answering. All responses will be held as confidential as possible. The results will be reported in summary format and, individual responses will not be identifiable. At the top right corner of the first page you will notice a code. This code is for identifying non-respondents for follow-up and will be destroyed before the data are analyzed.

For your convenience, a postage-paid, self-addressed envelope is provided. Your participation by completing and returning the questionnaire by October 15, 2003 is greatly appreciated. Thank you in advance for your cooperation.

Sincerely,

Renee D. Chambers

Graduate Student
Harry N. Boone, Jr., Ph.D.

Assistant Professor 
APPENDIX C

Questionnaire 


\section{Tractor and ATV Safety Program: A Survey of Educational Activities for Youth}

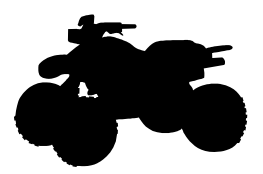

Please indicate your response to each of the following questions by checking the box(es) that best correspond to your response(s).

\section{Tractor Safety}

1. Do you offer educational activities for youth that address tractor safety?

Yes

No If no skip to question 13.

2. Who conducts the educational activities?

\section{County Extension Agent}

Other (please specify)

Agricultural Education Teacher

County Extension Agent \& Agricultural Education Teacher

3. What age groups do the educational activities target? (Mark all that apply.)

$$
\begin{aligned}
& <8 \text { year olds } \\
& 8-11 \text { year olds } \\
& 12-14 \text { year olds }
\end{aligned}
$$

15-17 year olds

18 year olds and up

4. What is the duration of the educational activities?

\section{$1 / 2$ day or less \\ $1-2$ days}

5. Who developed the educational activities?

County Extension Service

Agricultural Education Teacher
3 or 4 days

Other (please specify)

6. Which of the following are utilized in the instruction of the educational activities? (Mark all that apply.)

\section{Lecture}

Video

Demonstration
Use of a real tractor

Training manual

Other (please specify)

7. How often are the educational activities presented?

once a year

2-3 times a year
4 times a year or more 
8. How many youth participated in the educational activities during the past year?
$1-10$
$31-40$
$11-20$
$41-50$
$21-30$
$50+$

9. To whom are the educational activities available? (Mark all that apply.)

4-H youth

Other (please specify)

FFA youth

10. Which of the following topics are covered in the educational activities? (Mark all that apply.)

$\square$ Tractor rollovers
$\square$ Passengers
$\square$ Seat belts
Power Take-Off

Maintenance

Other (please specify)

11. How effective are the educational activities for educating youth on tractor safety?

Not effective

Somewhat effective
Very effective

12. Is certification offered to $15 / 16$ year olds that complete the educational activities?

$\square$ Yes

$\square$ No

13. Do you feel tractor accidents are a problem in your county?

$\square$ Yes

$\square$ No

14. Do you feel additional tractor safety programs are needed in your county?
$\square$ Yes
$\square$ No

\section{All-Terrain Vehicle Safety}

15. Do you offer educational activities for youth that address All-Terrain Vehicle (ATV) safety?

Yes

No If no, skip to question 26. 
16. Who conducts the educational activities?

County Extension Agent

Agricultural Education Teacher

County Extension Agent \& Agricultural Education Teacher

17. What age groups do the educational activities target? (Mark all that apply.)
$<8$ year olds
8 -11 year olds
12-14 year olds

18. What is the duration of the educational activities?
Other (please specify)
15-17 year olds

18 year olds and up
$1 / 2$ day or less
3 or 4 days
1-2 days
Other (please specify)

19. Who developed the educational activities?

County Extension Service

Agricultural Education Teacher

Other (please specify)

20. Which of the following that are utilized in the instruction of the educational activities?

(Mark all that apply.)
Lecture
Video
Demonstration

Use of a real ATV

Training manual

Other (please specify)

21. How many youth participated in the educational activities in the past year?
$1-10$
$31-40$
$11-20$
$41-50$
$21-30$
$50+$

22. How often are the educational activities available? (Mark all that apply.)
Once a year
$\square 4$ times a year or more
$\square$ 2-3 times a year

23. To whom are the educational activities available? (Mark all that apply.)
4-H youth
Other
FFA youth 
24. Which of the following topics are covered in the educational activities? (Mark all that apply.)
Helmet use
$\square$ Rider dynamics (operator age, size of
Passengers ATV)
Use on paved roads
Laws
Maintenance
Other

25. How effective are the educational activities for educating youth on ATV safety?
Not effective
Very effective

Somewhat effective

26. Do you feel that ATV accidents are a problem in your county?

$\square$ Yes

$\square$ No

27. In your perception, what is the main type of ATV accidents in your county?
Agricultural ATV use
$\square$ Recreational ATV use

28. Do you feel additional ATV safety programs are needed in your county?

$\square$ Yes

$\square$ No

29. This questionnaire was completed by a/an:
$\square$ Secondary Agricultural Educator
$\square$ Consumer Sciences Extension Agent
Agricultural Extension Agent
Other
$\square$ 4-H Extension Agent

Thank you for choosing to complete this questionnaire. Freel free to wite additional comments on the back of the swrey and then place the questionnaine in the returnenvelope and send to my address. 
APPENDIX D

Responses to Open-Ended Questions 


\section{RESPONSES TO OPEN ENDED QUESTIONS}

Responses from Extension agents

\section{$\underline{\text { Tractor Safety }}$}

2. Who conducts the educational activities?

Other
1. Farm Bureau
2. other speakers
3. FFA Alumni
4. Bob Yeager
5. Farm Bureau
6. Progressive Farm Safety Day Camp
7. volunteer
8. Farm Bureau
9. 4-H project \& Farm Safety Day

5. Who developed the educational activities?

Other

1. Dept. of Ag.

2. Progressive Farm Safety Day Camp

3. Bob Yeager

4. Farm Bureau

5. Progressive Farmer or qualified volunteer

6. Farm Bureau

7. WVU \& Progressive Farm Program

6. Which of the following are utilized in the instruction of the educational activities?

(Mark all that apply.)

Other

1. Tractor Safety Brochure, Lawn mower safety brochure, ATV safety brochure

2. 4-H project book

3. 4-H project book

4. Q\&A

9. To whom are the educational activities available? (Mark all that apply.)

Other

1. school students

2. 3rd graders in school system

3. all youth

4. School group

5. school \& farm children

6. Farm meetings, Livestock groups

7. any youth

8. local schools

9. adults 
10. $5^{\text {th }}$ graders

10. Which of the following topics are covered in the educational activities? (Mark all that apply.)

Other

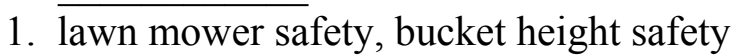

2. PTO

\section{All-Terrain Vehicle Safety}

16. Who conducts the educational activities?

Other

1. County Sheriff Dept., Farm Bureau

2. club/organizational leaders, 4-H program assistant

3. ATV Safety instructor

4. video

5. trained speaker

6. Farm Bureau

7. WVDA

8. trained ATV person

9. volunteer

10. sales representative

11. Farm Bureau

12. Progressive Farmer Farm Safety Day Camp

18. What is the duration of the educational activities?

Other

1. 1 hour

19. Who developed the educational activities?

Other

1. FBI

2. Progressive Farm Safety Day Camp

3. established materials

4. Farm Bureau

5. WVDA

6. WVU Health \& Safety

20. Which of the following are utilized in the instruction of the educational activities? Other

1. ATV Safety Brochure

2. Health Fair

23. To whom are the educational activities available? (Mark all that apply.)

Other

1. school students 
2. 3rd graders in Nicholas County

3. General public

4. 4th graders

5. school children \& people who purchase ATV's

6. any youth

7. elementary schools

8. adults

9. 5th graders

24. Which of the following topics are covered in the educational activities? (Mark all that apply.)

Other

1. How to turn down a ride if more than one rider on ATV especially if parent tells you to get on.

29. This questionnaire was completed by a/an:

Other

1. CRED Ext. Agent

2. 4-H program assistant

3. 4-H program assistant

4. Program Assistant 4-H Youth Development

5. other Extention agent

6. single county agent

Responses from agriculture educators

\section{$\underline{\text { Tractor Safety }}$}

2. Who conducts the educational activities?

Other

1. Farm Bureau

2. Fire \& Rescue

3. FFA Alumni

4. Progressive Farmer Farm Safety Day Camp, FFA students, teen leaders, 4-H leaders

4. What is the duration of the educational activities?

1. 3-5 class periods \& tractor driving contests

2. 10 days

3. 2 weeks

5. Who developed the educational activities?

Other

1. Fire \& Rescue

2. Farm Bureau 


\section{FFA}

6. Which of the following are utilized in the instruction of the educational activities? (Mark all that apply.)

Other

1. Power point

2. Transparencies

9. To whom are the educational activities available? (Mark all that apply.)

Other

1. Ag. Ed II classes

2. Progressive Farm Safety Day Camp is for all 4 th graders in the county

3. high school students

4. 6th grader

5. Ag. Ed. Students

6. school students

7. Ag. Ed. Students

8. all 5th graders in the county and high school student

9. middle school students

10. Which of the following topics are covered in the educational activities? (Mark all that apply.)

Other
1. front end loader operation
2. safety
3. attachments
4. general driving skills
5. equipment
6. mowing safety
7. road safety operation
8. general safety handling skills

\section{$\underline{\text { All-Terrain Vehicle Safety }}$}

16. Who conducts the educational activities?

Other

1. Progressive Farmer Farm Safety Day Camps

2. FFA students \& alumni

3. FFA

4. ATV dealers

5.

18. What is the duration of the educational activities?

Other

1. 1-3 class periods 
19. Who developed the educational activities?

Other

1. Progressive Farmer

2. Farm Bureau

3. FFA

20. Which of the following are utilized in the instruction of the educational activities?

Other

1. reference materials

23. To whom are the educational activities available? (Mark all that apply.)

Other

1. all 4 th graders in the county

2. 6th graders

3. middle school

4. school students

5. middle school students

6. 8th graders 
APPENDIX E

Comments 


\section{COMMENTS}

1. The deaths in our county from ATV accidents are most directly related to alcohol and drug abuse and driving speed. I'm not sure of any deaths when ATV's are properly operated. I'm strongly opposed to taking them off of roads because farmers need the access to different parts of their farms.

2. I have been on study leave but in the last month I am aware of 2 deaths related to ATV's. A 13 year old and a 34 yr old.

3. Tractor and ATV safety are topics covered on a year round basis by this Extention agent and especially during Spring, Summer, and Fall when farm equipment is more likely to be in use and on public roads.

4. Tractor accidents- a problem - No, But loss of one life is one too many. We have many folks who feel - It won't happen to me.

5. Cabell County Farm Bureau would be a good place to offer both kinds of training.

6. ATV safety not addressed for the last 3-4 years, since WVU Extension dropped the 4-H ATV Project and said we should not conduct the programs (due to liability issues). Several Grant County youth have been killed on ATV's.

7. Two or three youth were killed last year in this area. The 4-H was told by WVU not to do ATV 4-H program. ATV safety a more prevalent youth problem than tractors (more youth on ATV's).

8. ATV on hard roads are getting out of hand. It is really dangerous and sad. How do you legislate "common sense?"

9. ATV \& Tractor safety education are greatly needed. My understanding is that WVU Extension no longer wants us to do ATV Safety Education for liability reasons.

10. I started as Extension Agent in May 2003, so we haven't had a safety program this year. However, I was able to obtain a Progressive Farmer Farm Safety Day Camp for 2004. This camp will cover tractor, ATV and many other safety issues. The extension office and our county Farm Bureau chapter are working together to plan the event.

11. Agriculture is not a big business in this county. Still, the positive impact that a safety program would have would be worthwhile. The 4-H is in the process of expanding new ATV safety/training materials. As those become available, they will be offered to $4-\mathrm{H}$ participants and the general public.

12. There are very few farms with children. Tractor safety should be available for those 
that are on farms.

13. Have not had ATV educational activities since 4-H dropped the program.

14. I have been doing this job for two people and had a full plate before that. I believe these safety programs are important, but I cannot include them.

15. Not permitted to offer ATV educational activities, but would love to.

16. I teach greenhouse technology and small animal care. Tractor and ATV safety is not part of the curriculum.

17. A kid was killed last week.

18. In this county our fourth graders participate in Progressive Farmer's Farm Safety Day Camp. They cover a wide variety of Agriculture Safety issues.

19. I don't feel tractor accidents are a problem in this county, but I hear of near accidents from students. Our alumni is considering ATV safety program for their Spring Farm Fest. I don't feel ATV accidents are a problem is this county or at least not many have been reported by the media. Adults that purchase ATV's should be educated as to why their children need an ATV safety program.

20. I think tractor accidents are a problem in every county. We are thinking about offering ATV educational activities.

21. ATV accidents occur due to reckless misuse of the machine by teenage and young men under 25. They know not to do what they do, but feel invulnerable and like the rush of this type of driving. Laws need to change and be enforced. Parents need to closer supervise what children do.

22. I feel there are too many tractor accidents in this county. I had a former student lose her life as a result of an ATV accident.

23. I had a student in class whose brother was killed riding an ATV on a county road. I am planning on addressing ATV safety in class.

24. The ATV companies in our area offer safety courses and give participants "reward" money to participate. Of the tractor accidents in our area, both were experienced operators who tried to overdo the limitations of the machines and they flipped.

25. Very timely study. 


\section{VITA}

\section{Renee D. Chambers}

402 W. Gravel Lane

Romney, WV 26757

\section{Education}

May 2002

Bachelors of Science Degree in Agribusiness Management and Rural Development

West Virginia University

May 2004

Masters of Science Degree in Agriculture Education West Virginia University

Work Experience

January 2004-present

August 2002-January 2003

May 2002 - August 2002

May 2001 - May 2002

Volunteer Experience

June - August 2000

Honors and Activities
Substitute Teacher

Hampshire County, WV

Graduate Assistant

Davis College of Agriculture Forestry, and Consumer Sciences

West Virginia University

Research Assistant Aquaculture Team

Davis College of Agriculture Forestry, and Consumer Sciences

West Virginia University

Research Assistant Rumen Fermentation Profiling Laboratory

Davis College of Agriculture Forestry, and Consumer Sciences

West Virginia University

Mentor Energy Express

Americorps National Service

- Outstanding Senior in the Division of Resource Management

- Graduated Summa Cum laude

- National Society for Collegiate Scholars

- WVU Graduate Student Council

- WVU Woodsmen Team

- WVU Forestry Club 